\title{
Palaeogeography of tropical seasonal coastal wetlands in northern Britain during the early Mississippian Romer's Gap
}

David Millward ${ }^{1 *}$, Sarah J. Davies², Peter J. Brand ${ }^{1}$, Michael A. E. Browne ${ }^{1}$, Carys E. Bennett ${ }^{2}$, Timothy I. Kearsey ${ }^{1}$, Janet E. Sherwin ${ }^{2}$ and John E. A. Marshall ${ }^{3}$

${ }^{1}$ British Geological Survey, The Lyell Centre, Edinburgh EH14 4AP, UK (Email: dmill@bgs.ac.uk )

${ }^{2}$ School of Geography, Geology and the Environment, University of Leicester, Leicester LE1 7RH, UK

${ }^{3}$ Ocean and Earth Sciences, University of Southampton, National Oceanography Centre, European Way, Southampton SO14 3ZH, UK

*Corresponding author: David Millward, dmill@bgs.ac.uk

Running head: Romer's Gap palaeogeography

This is the authors' version of the manuscript accepted (2 August 2018) for publication in the Vertebrate Evolution part of Earth \& Environmental Science Transactions of the Royal Society of Edinburgh, published by Cambridge Journals.

The published version can be accessed through the following doi Doi:10.1017/S1755691018000737 
24

\section{Abstract}

The lower Mississippian Ballagan Formation of northern Britain is one of only two successions worldwide to yield the earliest known tetrapods with terrestrial capability, following the endDevonian mass extinction event. Studies of the sedimentary environments and habitats in which these beasts lived have been an integral part of a major research project into how, why and under what circumstances this profound step in the evolution of life on Earth occurred. Here, a new palaeogeographic map is constructed from outcrop data integrated with new and archived borehole material. The map shows the extent of a very low-relief coastal wetland developed along the tropical southern continental margin of Laurussia. Coastal floodplains in the Midland Valley and Tweed basins were separated from the marginal marine seaway of the Northumberland - Solway Basin to the south by an archipelago of more elevated areas. A complex mosaic of sedimentary environments is juxtaposed, and included fresh and brackish to saline and hypersaline lakes, a diverse suite of floodplain palaeosols and a persistent fluvial system in the east of the region. The strongly seasonal climate led to the formation of evaporite deposits alternating with flooding events, both meteoric and marine. Storm surges drove marine floods from the SW into both the western Midland Valley and Northumberland - Solway Basin; marine water also flooded into the Tweed Basin and Tayside in the east. The Ballagan Formation is a rare example in the geological record of a tropical, seasonal coastal wetland that contains abundant, small-scale evaporite deposits. The diverse sedimentary environments and palaeosol types indicate a network of different terrestrial and aquatic habitats in which the tetrapods lived.

Key words:

Ballagan Formation; coastal wetlands; Midland Valley of Scotland; palaeoenvironment; Tournaisian; Tweed Basin 


\section{(Introduction)}

The Mississippian (Tournaisian) Ballagan Formation of northern Britain hosts a diverse assemblage of vertebrate fossils, including the earliest known tetrapods with terrestrial capability (Clack 2002; Clack \& Finney 2005; Smithson et al. 2012; Clack et al. 2016; Smithson \& Clack, in press). This is one of only two successions in the world where such fossils have been found within the period of about 15 million years at the beginning of the Carboniferous that has become known as Romer's Gap. The other is the Horton Bluff Formation in Nova Scotia, Canada (Anderson et al. 2015), which at this time was relatively close along the southern margin of Laurussia. The emergence of tetrapods on land and their subsequent diversification follows the mass extinction events in late Devonian times (Kaiser et al. 2015). Understanding how, why and under what conditions this step change in the evolution of life on Earth occurred was part of the remit of the TW:eed Project led by Jenny Clack from 2012 until 2016. So, what were the landscape, palaeoenvironments and habitats like at this time?

Francis et al. (1970) and later studies have all inferred a coastal floodplain setting, though earlier, Belt et al. (1967) had proposed a marginal marine to restricted marine environment for dolostone deposition in the Ballagan Formation of the Midland Valley of Scotland. Anderton's (1985) conceptual facies model for the important fish-bearing succession at Foulden in the Tweed Basin was based on detailed sedimentary logging. This type of model has been developed further by Bennett et al. (2016, 2017), Kearsey et al. (2016), and Millward et al. (2018) from detailed investigations of sandy siltstones, ichnofacies, palaeosols and evaporite-rocks displayed in the successions through the formation exposed at Burnmouth and in the cores from the Norham West Mains Farm Borehole, near Berwick upon Tweed (Fig. 1). All of these models show the rapidly changing character of the sedimentary environments in the rock record, suggesting the juxtaposition of a mosaic of distinctive habitats within a strongly seasonal, tropical coastal wetland. These studies are applicable particularly to the Tweed Basin (Fig. 1), but how do they extend across the broader region of northern Britain? This is important because the palaeogeography of the region and its control on the distribution of palaeoenvironments and habitats may have played a role in shaping vertebrate evolution.

The Tournaisian palaeogeography of the Midland Valley, and the Tweed and Northumberland - Solway basins presented here has its origins in the seminal atlases of the UK by Wills (1951) and Cope et al. (1992). The TW:eed Project studies have provided greater clarity of detail and connections across the region between the sedimentary environments, habitats and the tetrapods that lived in them (Clack et al. 2016). The new map combines data from field sections and borehole records through the Ballagan Formation in the Midland Valley and Tweed Basin and includes reflections on published interpretations of the Northumberland - Solway Basin. These 
investigations provide new insights into this rare example in the geological record of an equatorial seasonal coastal wetland.

\section{Regional setting and stratigraphy}

During the early Mississippian, interconnected strike-slip fault-controlled sedimentary basins opened across northern Britain as a result of the breakup of the equatorial, southern part of the Laurussian continental margin (Coward 1993; Domeier \& Torsvik 2014). The northern basins include those in the Midland Valley, Tweed and Northumberland-Solway regions. Volcanism accompanied opening of the Tweed and Northumberland-Solway basins (Leeder 1974a; Chadwick et al. 1995). The early sedimentary fill to the basins comprises the Ballagan Formation, which was preceded by the upper Devonian Kinnesswood Formation and succeeded in various parts of the region by the Clyde Sandstone, Garleton Hills Volcanic, Lyne and Fell Sandstone formations (Figs 1, 2).

The Ballagan Formation is preserved at outcrop and in the subsurface across the Midland Valley and Tweed Basin, and this passes southward and stratigraphically upward into the Lyne Formation in the Northumberland-Solway Basin (Fig. 2). The Ballagan Formation consists of grey siltstone and thin beds of argillaceous ferroan dolostone (historically referred to as 'cementstone'), with varying proportions of sandstone, flood-deposited sandy siltstone, palaeosols and evaporiterock (Anderton 1985; Scott 1986; Andrews et al. 1991; Andrews \& Nabi 1994, 1998; Bennett et al. 2016; Kearsey et al. 2016; Millward et al. 2018). The formation is best exposed in the $520 \mathrm{~m}$ thick, vertically dipping, coastal section at Burnmouth (Fig. 1). Though a late Tournaisian, CM Miospore Biozone age (e.g. Neves et al. 1973; Neves \& loannides 1974; Stephenson et al. 2002) has been determined for the formation in central Scotland, Smithson et al. (2012) recorded earliest Tournaisian, VI Biozone miospores from the base of the formation at Burnmouth. Most recently, Marshall et al. (this volume) provide evidence that in the Tweed Basin the formation spans the Tournaisian. In East Lothian, the upper part of the formation has yielded early Visean Pu Biozone miospores (Neves et al. 1973; Neves \& loannides 1974); these upper beds are therefore laterally equivalent to the Clyde Sandstone Formation of the west of the Midland Valley which is inferred to be lower Visean (Waters et al. 2011).

The thickness of the Ballagan Formation ranges from a few tens of metres on the Isle of Bute, to $80 \mathrm{~m}$ in north Arran (Young \& Caudwell 2012), $150 \mathrm{~m}$ in the west of the Midland Valley and in Fife, up to $355 \mathrm{~m}$ in Ayrshire (Stephenson et al. 2002), and possibly up to $900 \mathrm{~m}$ west of Edinburgh (Fig. 1; Mitchell \& Mykura 1962). At least $418 \mathrm{~m}$ are present in East Lothian, but only $200 \mathrm{~m}$ at Birnieknowes at the NE margin of the Southern Upland massif. Approximately $520 \mathrm{~m}$ occur in the Tweed Basin whereas in the Northumberland - Solway Basin Tournaisian and Chadian strata may be 
up to $3400 \mathrm{~m}$ thick in the centre of this asymmetric graben (Chadwick et al. 1995). The formation is absent from the central part of the Midland Valley, having been eroded during mid-Visean (Arundian) uplift prior to the Clyde Plateau volcanism (Millward \& Stephenson 2011).

In stark contrast to the Ballagan Formation, the Kinnesswood and Clyde Sandstone formations comprise braided fluvial sandstone in upward-fining cycles, interbedded with overbank red and purple mudstone, multiple intervals with carbonate nodules and thin beds of concretionary limestone ('cornstones'; Eyles et al. 1949; Read \& Johnson 1967; Francis et al. 1970; Leeder 1976; Leeder \& Bridges 1978; Young \& Caldwell 2011, 2012). The 'cornstones' are palaeosols with pedogenic carbonate nodules (Burgess 1961; Leeder 1976; Andrews et al. 1991; Wright et al. 1993).

In the Northumberland - Solway Basin the Lyne Formation (formerly Lower Border Group of e.g. Lumsden et al. 1967; Leeder 1975a, b) is Tournaisian and early Visean in age, and contains significant marine clastic and carbonate sedimentary rocks and fossils (Leeder 1974b; Brand 2018). The Lyne and Ballagan formations are overlain unconformably by the Fell Sandstone Formation in the Tweed Basin and eastern part of the Northumberland - Solway Basin. The Fell Sandstone is composed of a stacked succession of mainly coarse-grained sandstone deposited from the first major Carboniferous fluvio-deltaic system to cross the region (Kearsey et al. 2018).

\section{Methods}

The palaeogeography is reconstructed using data from field exposures across the Midland Valley and Tweed basins, and from about 40 borehole logs from the BGS archive that proved significant occurrences of Tournaisian strata. A sub-set of twelve boreholes, commissioned by BGS as part of the stratigraphical investigation of Upper Devonian and Mississippian rocks of the region from 196781, provide descriptions and consistent information on the spatial and temporal occurrence, context and general form of the different lithofacies. Cores have been retained for only one of these, the Glenrothes Borehole and visual inspection of these provided additional information.

It is to be expected that the archived logs vary in amount and quality of information they contain because they were made over more than 100 years. The BGS sub-set provides the greatest volume of data though even here variations in data quantity and quality arise because they were logged by different geologists. Information is particularly sparse on palaeosols and sandy siltstones. Palaeosols are under-described in UK geology generally, though rooted 'seat-earths' have long been recognized by Geological Survey staff because of extensive work in the coalfields. Sandy siltstone is a facies only recently identified from the Ballagan Formation and so is not recorded (Bennett et al. 2016). Therefore, interpretation of the facies from these boreholes (Table 1) is informed and 
benchmarked against the facies analysis of the Norham West Mains Farm Borehole undertaken by Bennett et al. (2016; table 1). This borehole is located in the Tweed Basin, about $10 \mathrm{~km}$ south-west of Berwick upon Tweed, and fully cored $491 \mathrm{~m}$ of the Ballagan Formation (Fig. 1; Millward et al. 2013).

The BGS collections contain macrofossils from the Ballagan and Lyne formations from 235 localities, including many of the boreholes, collected over a period of more than 100 years. The fossils have been re-examined for this study to ensure taxonomic consistency (Brand 2018). The biogeographical distribution of marine taxa and 'Estheria' are included herein as they provide additional insight alongside the sedimentary data. Raymond (1946, p 219) noted that 'Estheria' is an invalid name for a conchostracan genus as the name was pre-occupied, and he erected a number of genera in which to allocate the known species. Unfortunately, he did not allocate all the Scottish described species to his genera, and preservation of the material from the Ballagan Formation often precludes even a generic allocation.

\section{Sedimentary facies}

Facies identified in selected exposures and the archived borehole logs are described in Table 1, and examples illustrated in Figure 3. Summary statistics for selected features in the borehole logs are given in Table 2. The stratigraphical variation of facies across the Midland Valley is shown in Figures 4 and 5.

The succession in the west and north of the Midland Valley mostly comprises small-scale intercalations of packages of dolostone and grey siltstone, along with heterogeneous siltstone and fine-grained sandstone, and locally, evaporite-rock; these abruptly interdigitated facies constitute the saline and hypersaline lake and overbank facies associations (Figs 3,4 ). Laterally continuous distinctive units that might be suitable for correlation across the region are not present, though the uppermost part of the formation is sand-rich in parts. At the base of the formation in Fife and Tayside, a unit of distinctive dolostone beds, 32 m-thick, comprises the Mains of Errol Member (Browne 1980). By contrast, in the east, the succession is more heterogeneous with thick distinctive packages of, for example, fluvial sandstone and floodplain-lake siltstones within a mixed assemblage of fluvial and overbank facies associations (Figs 3,5). The position of the base of the Pu Miospore Biozone suggests that some of the packages in East Lothian may be correlated, at least over a distance of about $15 \mathrm{~km}$. 


\subsection{Siltstone, dolostone and evaporite facies}

Thin beds of micritic ferroan dolostone interbedded with planar laminated, grey siltstone are the defining characteristic of the Ballagan Formation. Siltstone occurs in both the saline and hypersaline lake facies association, and the overbank facies association (Fig. 3). Laminated grey siltstone comprises a high proportion of the fines component in some of the boreholes, for example $99 \%$ in Blairmulloch and 89\% in Loch Humphrey (Table 2), but is generally lower in the East Lothian boreholes. Thick packages of laminated grey siltstone in the boreholes with high proportions of fine sediment likely represent floodplain-lake deposits, though these may include misidentified thin beds of sandy siltstone. Laminated grey siltstone associated with the upper part of massive and crossbedded sandstone may fill fluvial channels. The overbank facies association includes grey, yellow, red and purple siltstone, only some of which is described as having traces of bedding; these may be palaeosols, but the descriptions are insufficient for a diagnosis.

After removing the sandstone component from each borehole, dolostones comprise 3 to $21 \%$ of the thickness of the remainder of the succession. The number of dolostone beds varies from nine in the Ascog Borehole to 277 in Norham, with the average thickness ranging from $9 \mathrm{~cm}$ in Ascog to $34 \mathrm{~cm}$ in East Linton (Table 2). Thus, in the boreholes of the western and northern part of the region, dolostone beds occur on average every $0.9 \mathrm{~m}$ (Glenrothes) to $1.7 \mathrm{~m}$ (Knocknairshill, Blairmulloch; Fig. 3). By contrast, dolostone beds are, on average, less common in the East Lothian boreholes, but there the concentration of dolostone beds within packages of laminated grey siltstone up to $35 \mathrm{~m}$ thick is strongly evident, with significant packages of overbank siltstone and fine-grained sandstone devoid of dolostone beds (Fig. 5).

Apart from the thickness, few descriptive details of the dolostone beds are typically given, though some are described as ironstone (Davies et al. 1986; Greig 1988). Belt et al. (1967), Francis et al. (1970) and Scott (1986) identified dolostone nodules, laminated beds (Fig. 8D), evaporite-bearing beds and massive beds; the last of these become more argillaceous at the base and top. Identification of these differing facies is aided by slicing the cores, but information from the borehole logs is insufficient to make the distinctions in all but the evaporite-bearing dolostones.

Small-scale evaporite deposits are a characteristic of the Ballagan and other Tournaisian formations in the British Isles (Millward et al. 2018). They are distributed spatially and temporally throughout the succession in the Midland Valley and Tweed Basin, though they are absent from the Lothians and from the area bordering the Highlands (Figs 4, 5). Nodules of gypsum occur in siltstone and dolostone; calcite and dolomite pseudomorphs occur in the latter at Burnmouth and in some of the boreholes (Scott 1986; Millward et al. 2018). Siltstone pseudomorphs after hopper crystals of 
halite are recorded locally in boreholes (Fig. 4) and in exposures, for example in the Langholm area, Chattlehope Burn, Northumberland and Willie's Hole, Scottish Borders (Leeder 1974b; Cater et al. 1989).

\subsection{Mains of Errol Member}

The Mains of Errol Member (Fig. 4; Browne 1980) comprises beds of hard dolomicrite, with a characteristic reddened, cracked and 'pseudobrecciated' profile (Fig. 6). The top of each profile is a sharp planar contact. Roots and burrows are absent; ostracods and fish fragments are rare and other fossils absent. Dolostone beds, 0.22-1.70 m thick, are either stacked on top of each other, or they are intercalated with units of laminated siltstone or sandy siltstone. The dolostone is composed of planar-textured subhedral dolomite with crystal size up to $10 \mu \mathrm{m}$. A pseudobrecciated texture shows 'clasts' of finer grained dolomite set in coarser grained dolomite. Quartz grains scattered throughout the rock are etched, suggesting corrosion in alkaline fluids. A few rhombohedra composed of dolomite aggregates are probably pseudomorphs after gypsum. Scattered clasts up to $500 \mu \mathrm{m}$ composed of chlorite and feldspar may be volcanic in origin.

From just above each dolostone unit base, isolated, narrow sinuous cracks widen upwards as they unite with adjacent ones (Fig. 6). At their upper termination against subhorizontal planar dislocations these cracks are polygonal and up to $20 \mathrm{~mm}$ across on the bedding surface. The cracks are filled with Fe-rich claystone. Above the cracked zone, $20-40 \mathrm{~cm}$ of dolostone are intensely brecciated, with poorly sorted, angular clasts of dolostone from 1 to $20 \mathrm{~mm}$ across, set in a Fe-rich claystone. In this zone and the top part of the underlying cracked zone, low-angle, concave-upwards dislocations resemble pedogenic slickensides. In the most fully preserved profiles the uppermost 5$10 \mathrm{~cm}$ are composed mainly of red-brown, Fe-rich claystone, with sporadic dolostone clasts, $1-5 \mathrm{~mm}$ across. Similar beds have been reported from a borehole in the Stirling area (Francis et al. 1970, plate 4, fig.7).

\subsection{Sandstone}

Sandstone facies occur within the fluvial and overbank facies associations (Bennett et al. 2016). All sandstone contains abundant partings of mica and carbonaceous detritus. The proportion of sandstone in the succession varies across the region (2-46\%; Table 2), with the higher amounts in East Lothian and the Tweed Basin (24\% in East Linton Borehole, 32 \% in Spilmersford and $46 \%$ in Birnieknowes (Fig. 7). By contrast, in boreholes in the north of the Midland Valley, sandstone is most commonly seen at the base and top to the formation, though in the Ascog Borehole it occurs throughout (Fig. 4). Units up to $3 \mathrm{~m}$ thick occur in all the boreholes, with the median occurrence less than $50 \mathrm{~cm}$ thick (Fig. 7). Typically, these thin units of sandstone are described as fine-grained and 
ripple-laminated or cross-laminated. Many are interbedded with siltstone and are interpreted as deposited by overbank flooding and crevasse-splays. A few units in this interval are recorded as having a sharp, erosive base and massive or cross-bedded and may represent channel sandstone bodies.

By contrast, the Blairmulloch and East Lothian boreholes also contain sandstone units more than $3 \mathrm{~m}$ thick (Fig. 7). Though the number of such units is small, they comprise a high proportion of the total thickness of the sandstone component in the succession; for example three units in Spilmersford comprise $31 \%$ of the sandstone thickness and in Birnieknowes 63 \% (Table 2). These sandstone bodies are described as sharp-based, medium and coarse grained, massive or crossbedded (Fig. 3) and may include mudstone rip-up clasts and conglomerate layers in the lower part. A thin upper part typically is finer grained and planar laminated to ripple laminated. Thicknesses vary from just a few metres up to $15 \mathrm{~m}$ in the Spilmersford, East Linton and Birnieknowes boreholes. The $11.4 \mathrm{~m}$ thick sandstone unit illustrated in Figure 3 is typical of many, comprising stacked subunits separated by a thin bed of siltstone, suggesting that the thicker sandstone bodies represent multiple-storey channel fills. Lenticular beds of conglomerate at the base of sandstone units at Burnmouth host disarticulated vertebrate bones.

The geometry of one of these sandstone units is seen in the river cliff of the Whiteadder River at Edington Mill [NT 894 548] (Fig. 8A, C). The lower part of the channel cuts sharply down about $4 \mathrm{~m}$ into the underlying siltstone-dolostone succession. Rotated blocks of siltstone-dolostone suggest that the channel margin collapsed during formation (Fig. 8C). The channel fill shows lenticular units of cross-bedded sandstone with lateral accretion at the channel base. Clasts of dolostone in the thalweg can be traced to a bed cut by the channel. Beds in the upper part of the channel thicken to the right in Figure 8A. Another unit, more than $20 \mathrm{~m}$ thick, near the top of the formation, and exposed along the SE bank of the River Tweed at Norham is strongly trough crossbedded with sediment transport consistently towards the SW.

At the coastal locality of Burnmouth in the Tweed Basin, a number of sandstone fluvial bodies are exposed in the almost vertical strata of the wave-cut platform and cliff. Depicted on a geological excursion map, Scrutton \& Turner (1995) numbered the large sandstone bodies 1 (youngest) -14 (oldest). Analysis of these bodies indicates that a number are multistorey and multilateral, and can be traced across the wave-cut platform for up to a kilometre. Lateral accretion deposits (2-3 $\mathrm{m}$ thick) are recognized in several bodies. Whereas individual channels may only reach $3 \mathrm{~m}$ in thickness, one or two of the multistorey systems comprise a total in excess of $30 \mathrm{~m}$. In 
general, the erosive bases to the channels cut into the underlying floodplain sedimentary rocks, but some systems cut into the dolostones, representing lake deposits.

Poorly bedded volcaniclastic rocks within the Ballagan Formation are described here for the first time from the Spilmersford and East Linton boreholes (Fig. 5). They occur both within, and at the top, of the formation, interbedded with sandstone and siltstone. A unit in the lower part of the East Linton Borehole is $7.9 \mathrm{~m}$ thick with beds ranging from $24 \mathrm{~cm}$ to $1.5 \mathrm{~m}$ thick. They are composed of multi-coloured fragments of volcanic rock of medium sand through gravel grade, with some dolostone, siltstone and sporadic chert clasts. These rock types have not been reported from elsewhere in the formation.

\subsection{Emergent surfaces and palaeosols}

Desiccation cracks and brecciated, upper parts of beds, both at outcrop and in boreholes represent short-lived episodes of emergence and drying out of the sediment. At least 5 horizons are seen, for example, in the upper part of the shallowly dipping succession in the well exposed coastal section at Belhaven Bay, west of Dunbar (Fig. 8), but there is great variation in abundance across the Midland Valley (Fig. 9; Table 2). Glenrothes and East Dron borehole logs contain 138 and 110 horizons respectively, comparable to 131 in the Norham core of the Tweed Basin (Figs 3, 9). By contrast, the very low numbers of desiccated surfaces in the other boreholes may inversely relate to the high proportion of laminated grey mudstone present, representing extended periods of sedimentation in perennial bodies of standing water. Alternatively, the low numbers may reflect under-recording of detail.

The preservation of plant roots and palaeosols indicate established episodes of emergence and vegetation cover. Carpenter et al. (2015) interpreted the mottled red mudstone beds containing carbonate nodules and vertic cracks within the thin succession on the Isle of Bute as well drained, seasonally dry palaeosols. Near Foulden, Retallack \& Dilcher (1988) inferred that gleyed inceptisols were populated by small shrubby ferns such as Lyrasperma scotica and vertisols by tall forest trees such as the reconstructed Stamnostoma huttonense. Kearsey et al. (2016) described 216 palaeosols from the Norham core and 64 from the exposed section at Burnmouth in the Tweed Basin. Nineteen vertisols occur in the Norham core and 15 at Burnmouth, representing extended periods of stabilized floodplain. Some $60 \%$ of the vertisols have a gleyed top indicating that the soils were finally flooded by surface waters (Kearsey et al. 2016).

Few palaeosols are described in the archived borehole logs (Table 2). In the Glasgow and Ayrshire logs there are sporadic mentions of 'seatearths' and 'seat clay', typically associated with carbonized root traces; the absence of coals capping these suggest that they probably equate to the 
gleyed inceptisols of Kearsey et al. (2016). Roots in the top of sandstone beds are likely the entisols described by Kearsey et al. (2016). However, the depth and form of rooting is not given. Massive, red-, brown- and yellow-mottled siltstone, particularly in the East Lothian boreholes and sporadically elsewhere, might suggest that vertisols are also present there, but indicative evidence of vertic cracks and pedogenic slickensides is missing. However, in many of the logs from the west and north of the Midland Valley, the high proportion of laminated grey siltstone present would seem to preclude the presence of well-developed palaeosols from those parts of the succession. This is also the case with the Glenrothes core, visual inspection of which showed the presence of very few palaeosols of any type.

\subsection{Sandy silltstone}

Matrix-supported sandy siltstone with millimetre-sized rock clasts and bioclasts was first described from the Ballagan Formation from the Norham core and at Burnmouth by Bennett et al. (2016). The 146 and 71 beds respectively from the two sections are mostly less than $1 \mathrm{~m}$ thick; sandy siltstone comprises about $6 \%$ of the succession and typically overlies palaeosols or desiccated horizons. The deposits have lateral extents of up to several tens of metres at Burnmouth. The beds are inferred to have been generated by episodes of high rainfall and deposited as unconfined, cohesive flows across the floodplain, forming temporary pools and small lakes. Bennett et al. (2016) suggested that because of the small size of the clasts, the facies could be misinterpreted as a massive siltstone, with colour varying from black, grey and red to light green. Thus, it is likely that the sandy siltstone facies is more widespread in the Ballagan Formation than hitherto reported. This facies is not described in many of the borehole logs throughout the Midland Valley, but inspection of the Glenrothes core revealed at least three beds in the Mains of Errol Member. Described in the logs as 'mudstone breccia', these are 10-44 cm thick and composed of greenish grey (?)dolomitic siltstone with elongate irregular clasts of dark grey siltstone (Fig. 8E).

\subsection{Fauna and flora}

The Ballagan Formation has a generally sparse and low-diversity invertebrate fauna dominated by bivalves (particularly Modiolus latus), ostracods, shrimps and other arthropods (Cater et al. 1989), along with rarer occurrences of Spirorbis, Serpula and scolecodonts (Bennett et al. 2017). In a few beds invertebrates may be locally common (Brand 2018), and Modiolus and ostracods can occur in large numbers (Williams et al. 2005, 2006). By contrast, the vertebrate fauna appears to have been diverse with actinopterygians, dipnoans, chondrichthyans, acanthodians and tetrapods (e.g. Andrews 1985; Gardiner 1985; Clack 2002; Clack \& Finney 2005; Smithson et al. 2012, 2016; Carpenter et al. 2015; Clack et al. 2016; Richards et al. in press; Smithson \& Clack in press). A varied flora has been reported from plant elements and palynomorphs (Scott \& Meyer-Berthaud 1985; 
Retallack \& Dilcher 1988; Bateman \& Scott 1990; Stephenson et al. 2004); furthermore, indeterminate plant debris is a ubiquitous component of many lithofacies.

In the BGS fossil collections (Brand 2018), most of the invertebrate species from the Ballagan Formation are considered to be either non-marine or euryhaline. Important indicators of terrestrial lakes are the sporadic conchostracans which occur in the Midland Valley and Tweed Basin, but which are absent from the Northumberland - Solway Basin (Fig. 10). Recorded from several levels in most of the boreholes (Figs 4, 5, 9), they are particularly abundant in the East Linton Borehole (340.66$347.50 \mathrm{~m}$ depth), where specimens were recorded from 8 levels within $8 \mathrm{~m}$ of dark purple and grey, bedded or poorly bedded, mudstone and siltstone.

There is no sedimentary evidence for fully established open marine conditions across the Midland Valley and Tweed Basin: for example, carbonate rocks of this type are absent, as are successions indicative of the upward transition from storm wave-base to shore face. Beach and tidal deposits have also not been reported. However, marine fossils are recorded sporadically. Typically, the occurrences are restricted to a single taxon per interval and include orthocone nautiloids, the bivalves Schizodus pentlandicus?, Phestia traquairi, Sanguinolites cf. clavatus, S. aff. striatolamellosus and S. cf. roxburgensis, Cardiomorpha, very rare rhynchonellid brachiopods and Lingula mytilloides. The shells are disarticulated or fragmentary, except at one level (496.17 m depth) from the Norham Borehole where an articulated Phestia traquairi was found vertical to bedding, in life position. Sanguinolites, Cardiomorpha, orthocones and brachiopods occur in the west of the Midland Valley, notably in Ayrshire but also near Glasgow (Fig. 10). Also, four marine intervals are present in the lower part of the Blairmulloch Farm Borehole. Similarly, an orthocone and Sanguinolites occur near the top of succession in the East Dron Borehole. Larger marine macrofossils occur at five intervals in the Norham core. In stark contrast, at outcrop along the northern flank of the Northumberland Basin, records of marine species are more widespread and assemblages from individual localities are more varied (Fig. 10; Brand 2018).

A significantly greater cryptic marine influence has been demonstrated from 128 thin beds in the Norham core of a Chondrites ichnofacies, particularly within dolostones of the saline-hypersaline lake facies association (Bennett et al. 2017). These occurrences are described as single-tier colonisations, with a high ichnofabric index. By contrast, very few bioturbated cementstone beds were recorded in the Midland Valley borehole logs, where burrows and bioturbation are most commonly recorded in mudstone and siltstone (Table 2; Figs 3, 4, 5). 'Flat' burrows were noted in some finer grained rocks and simple vertical burrows in sandstone, but there are few records of the ichnotaxa present. Exceptions are in the East Linton Borehole where ?Monocraterion and Planolites 
were recorded from ripple-bedded sandstone. Eighteen beds containing scolecodont (marine polychaete) jaws were identified from grey siltstones in the Norham core (Bennett et al. 2017) providing more evidence of cryptic marine incursions.

\section{Palaeogeography}

The new map (Fig. 11) combines elements of the palaeogeography from throughout the Tournaisian, a period of some 12 million years. The map shows areas of more elevated land with a coastal floodplain occupying a broad swath through the Midland Valley into the Tweed Basin, and connected east of the Southern Uplands and Cheviot massifs to a shallow seaway in the Northumberland - Solway Basin. The western Midland Valley is connected through Northern Ireland to full marine conditions in the south of Ireland (Clayton \& Higgs, 1979; Clayton et al. 1986). At times, shallow saline lagoons were established in the Belfast Lough area, as evidenced by the presence of stromatolites at Cultra (Clayton 1986), and the thick succession of dolostone and evaporite containing marine invertebrates proved in the Belfast Harbour Borehole suggest restricted marine conditions (Smith 1986). The coastlines migrated from time to time in the NorthumberlandSolway Basin (Sherwin 2018), but storm-driven marine flooding (Bennett et al. 2017) reached much greater extents into the western Midland Valley and in the east.

Over most of the region, floodplain lakes and overbank facies are juxtaposed. Three floodplain-lake successions hosting significant fish communities are indicated on the Isle of Bute (Carpenter et al. 2015) in the Midland Valley, at Foulden in the Tweed Basin (Wood \& Rolfe 1985; Clarkson 1985) and in Coomsdon Burn on the flanks of the Northumberland - Solway Basin (Fig. 11; Moy-Thomas 1938). Detailed distributions are given where known for small-scale temporary inland ponds (see below), sabkhas and perennial hypsersaline lakes; the early Tournaisian Mains of Errol alkaline lakes in Fife and Tayside are also shown. Forested areas are known from the Tweed Basin and on the Isle of Bute, but were probably more extensive, particularly adjacent to upland massifs. The approximate likely extent of the belt of fluvial sandbodies that dominated the east of the Midland Valley and Tweed Basin in the upper part of the succession is indicated (Fig. 11). Alluvial fans along the margin of the Southern Uplands and Cheviot massifs are early features. The environments of the Northumberland - Solway Basin are described only briefly for context.

\subsection{Massifs}

Tournaisian strata are absent from the isolated outcrops of Carboniferous rocks in the western part of the Highlands of Scotland, which has long been regarded as terrestrial in the Tournaisian. This upland may have extended south to the Ochil Fault (Figs 1, 11), though this is difficult to prove. The Lower Devonian Ochil Volcanic Formation, which today forms the eponymous hills, comprises 
Page 14 of 36

$4102400 \mathrm{~m}$ of largely subaerial volcanic rocks that interdigitate north-eastwards with fluvial and

411 lacustrine rocks of the Arbuthnott Group (Stephenson et al. 1999). Though the sedimentary strata

412 may have been buried by up to about $3 \mathrm{~km}$ of later strata by the late Carboniferous (Marshall et al.

413 1994), it is possible that the core of the volcanic massif in what is now Fife and Tayside remained

414 elevated through early Carboniferous times.

South of the Midland Valley, an upland massif of Lower Palaeozoic rocks is inferred to approximate to the area of the modern-day Southern Uplands, extending south-westwards to include the Longford-Down massif in Northern Ireland. The Sanquhar and Thornhill coalfields crop out in a northerly trending half graben within the Southern Uplands. The oldest Carboniferous rocks are Pendleian in the former coalfield and upper Visean in the latter (Davies 1970; McMillan 2002). Furthermore, on the northern margin of the Northumberland - Solway Basin northerly derived palaeocurrent directions in the Whita Sandstone at the base of the Ballagan Formation suggest that the massif was a source of sediment and probably remained significantly elevated for much of the Tournaisian (Nairn 1958; Leeder 1974b).

Though the lower Tournaisian basalts of the Northumberland - Solway Basin margin were rapidly buried by the Ballagan Formation (Leeder 1974a), the eroded remains of the Middle Devonian Cheviot volcano probably stood above the floodplain. Relict outcrops of Ballagan Formation in the intervening ground suggest that the Cheviot massif was separated from the Southern Uplands. On the flanks of the Cheviot massif, alluvial fan conglomerates at Roddam Dene, Ramshope Burn and Windy Gyle reworked the volcanic rocks and granite (Purnell \& Cossey 2004). These rocks are thought to be coeval with the Kinnesswood Formation (Stone et al. 2010) and are therefore latest Devonian in age (Marshall et al. this volume). Seismic mapping and borehole interpretation across the Mid North Sea High suggest that several small elevated areas also persisted eastwards across the coastal plain (Arsenikos et al. 2018; Kearsey et al. 2018), like an archipelago separating the Tweed and Northumberland - Solway basins. To the south of the latter basin, the Manx - Lake District - Alston Block was also terrestrial at this time, with fluvial (possibly as valley fills) and alluvial fan deposits of the Marsett Formation on the northern flank of the Lake District and on the present day Pennine escarpment suggesting that that block had some relief (Burgess \& Holliday 1979). of the underlying Kinnesswood Formation, by local occurrences of massive carbonate-rock, several metres thick and typically associated with stringers, nodules and irregular masses of chert; these 
443 \& Caldwell 2011), Ayr (Burgess 1961), at Pease Bay [NT 795 712], east of Dunbar (Clough et al. 1910;

444 Andrews et al. 1991) and in the Tweed valley, about $5 \mathrm{~km} \mathrm{SW}$ of Coldstream, where the Carham 445 Limestone is at least $7.5 \mathrm{~m}$ thick (Carruthers et al. 1932). These are highly significant as they may 446 represent disconformity with a significant time span (Etthenson et al. 1988; Wright et al. 1993; 447 Alonso-Zarza 2003). The calcrete-bearing palaeosols may have formed in areas elevated above the 448 floodplain for a long time, perhaps up to several million years, for example as terraces adjacent to 449 upland areas or through tectonic uplift, or on terraces formed by uplift associated with volcanism 450 (Leeder 1976; Leeder \& Bridges 1978).

\section{1}

\subsection{Coastal floodplain of the Midland Valley and Tweed basin}

Over the western and northern parts of the Midland Valley boreholes show abrupt intercalations of facies belonging to the saline - hypersaline and overbank facies associations. Long core runs of grey laminated siltstone suggest perennial floodplain lakes dominated much of the area through the Tournaisian. The common fauna of these rocks are ostracods, which were locally monospecific and in great abundance (Stephenson et al. 2004a; Williams et al. 2006). Stable isotope analysis of the ostracod shells from different communities indicates that salinity of the lakes varied from brackish to saline and hypersaline (Williams et al. 2006), though later work indicated that the ostracods' calcite carapace had been recrystallized as a result of diagenetic alteration (Bennett et al. 2011).

It is difficult to estimate the size of the floodplain lakes. Unpublished studies of the laminated siltstone beds and dolostones at Burnmouth and in the Norham core by the authors suggest deposition in very shallow lakes up to a few kilometres across, based on the outcrops of planar beds of dolostone and their thickness on the foreshore at Burnmouth. Dolostones can be traced some $500 \mathrm{~m}$ or so, though some are less extensive, but no beds can be correlated between Burnmouth and Norham, a distance of about $10 \mathrm{~km}$. None of the lakes was thought to have been long-lived, with mud-cracks at the top of many of the thin units indicating drying out of the surface. However, the area west and north of Glasgow was repeatedly occupied by lakes throughout most of the formation. Similar lacustrine-dominated successions are recorded in the middle of the formation in the area between Spilmersford and East Linton in East Lothian, some $15 \mathrm{~km}$ apart suggesting a substantial area that was persistently occupied by lakes.

Thin intervals of overbank flood and crevasse-splay deposits become dominant sedimentary environments in the upper part of the formation around the Isle of Bute and west of Glasgow. Few palaeosols are recorded from this area though in the East Dron and Glenrothes boreholes in the NE, dried out surfaces are common (Table 2; Fig. 3). Vegetated land seems to have been sparse as indicated by the dominance of floodplain lakes. These features are well demonstrated by Figures 3 
476 (Glenrothes Borehole) and 4. Correlation between boreholes is not possible, suggesting a mosaic of 477 juxtaposed and ever-changing sedimentary environments. No aeolian deposits are known, though 478 differentiating these in fine-grained successions may be difficult.

A more complex picture occurs in the SE of the Midland Valley and in the Tweed Basin where overbank facies dominate and fluvial channel systems developed (Figs 3, 5). Brackish to saline floodplain lakes continue throughout, but are particularly concentrated in two 30-40 m thick 482 intervals of strata in the upper Tournaisian, as indicated by the base of the Pu Miospore Biozone 483 (Neves \& loannides 1974; McAdam \& Tulloch 1985). Waterlogged palaeosols appear to be more common in this region. Recognition of these is important because these are the likely habitat of the creeping lycopod Oxroadia, the spores of which are abundant where tetrapods have been located in the Burnmouth section (Clack et al. 2016). In the upper part of the succession in the Tweed Basin (Kearsey et al. 2016) and on the Isle of Bute (Carpenter et al. 2015), well developed reddened vertisols indicative of forests demonstrate areas of greater floodplain stability. Reddened siltstone and mudstone constitute a significant proportion of boreholes in the SE of the Midland Valley, suggesting that vertisols may have developed more widely in this region, but descriptions are insufficient to be secure in the interpretation.

\subsubsection{Perennial floodplain lakes with vertebrate communities. Fragmentary} vertebrate material including teeth, scales and spines is a common component of many of the floodplain lake successions. However, at least three of these successions have revealed more abundant and complete specimens within diverse communities that included bivalves, malacostracan crustacea and Spirorbis and these sites are located in Figure 11. The best studied of these is the Foulden Fish Bed which occurs at the top of a lacustrine succession that began development as a lycopod wetland, became a semi-permanent floodplain lake and finally was siltedup to return the area to a floodplain environment (Clarkson 1985; Wood \& Rolfe 1985). The abundant complete fish remains and beds of shrimps likely represent mass mortality events. Kills of this sort are well known in the seasonal tropics today, for example in northern Australia, where they result from sudden changes in water quality caused by the influx of sediment at the onset of the wet season (e.g. Townsend et al. 1992). The precise position of the Foulden Fish Bed within the Ballagan Formation is not known, though its outcrop location and its CM Miospore Biozone age (Clayton 1985) suggest the upper part. 
published sedimentary logs of the succession by Day (1970, p. 280) and Cater et al. (1989, fig. 6). However, the presence of nearly complete specimens of both fish and shrimps suggests similar palaeoenvironments in the upper part of the formation. Carpenter et al. (2015) described two fish beds, possibly from two different stratigraphical levels, on the Isle of Bute. Though the material is mostly fragmentary, it contains possible juveniles and the community occupied shallow fresh- to brackish water lakes.

\subsubsection{Temporary inland ponds. The presence of abundant, small temporary lakes is} revealed from the widespread occurrence of conchostracans across the Midland Valley and Tweed Basin (Fig. 10). Tasch $(1969,146-149)$ described the main habitat of modern conchostracans as small temporary inland ponds, generally no larger than about 0.4 hectares ( 1 acre) in extent. Modern forms have also been recorded from spring water, from the margins of large lakes in Africa and from coastal salt flats in Brazil. Further, he found that fossil forms may have inhabited temporary pools close to coastal areas subject to fluctuating tides, possibly in lagoons or at shorelines subject to marine inundations. Gueriau et al. (2016) also suggested that conchostracans typically inhabit temporary freshwater environments. Their discovery of resting eggs associated with conchostracans in a late Famennian deposit at Strud in Belgium suggests a mechanism of dispersal from such temporary environments and offers a capability of surviving seasonal desiccation.

\subsubsection{Sabkhas and hypersaline lakes. In the Tweed Basin evaporite-rocks are most} abundant in the lower part of the succession, but elsewhere these rocks occur throughout the formation (Fig. 4). In contrast, evaporite-rocks are notably absent from the SE part of the Midland Valley. Most of the evaporite occurrences are located within areas where there is evidence for marine flooding (see below). Millward et al. (2018) have described this unusual feature of seasonal coastal wetlands that developed in evaporative closed hypersaline lakes and perennial brine pans. Sabkhas, marsh and microbial mats surrounded some of these. Floodplain lake - evaporite cycles were illustrated from the Tweed Basin by Millward et al. $(2018$, fig 6) whereby flooding events over a palaeosol surface established a floodplain lake with a low diversity ichnofauna and invertebrate assemblage. Subsequent evaporation led to deposition of dolomite and hypersalinity ultimately to gypsum; saline groundwater and marine flooding events recharged the lakes.

4.2.4. Mains of Errol alkaline lakes. The reddened and pseudobrecciated dolostone beds that comprise most of the Mains of Errol Member in the NE of the Midland Valley probably represent similar lakes that were hypersaline and alkaline: repeated episodes of dolomite precipitation in shallow evaporating lakes, which dried out and desiccated. The very sparse, low- 
diversity fauna and lack of bioturbation suggest that these lakes were not conducive to life. The absence of roots suggests that the dried out lake beds were barren.

\subsubsection{Fluvial systems. The occurrence of thick packages of fluvial sandstone and} dominance of overbank siltstones over floodplain lakes suggests that a major fluvial system persisted for much of the Tournaisian in the east of the Midland Valley. Palaeocurrent indicators show sediment transport to the SW in the Tweed Basin, presumably contributing to the sediment budget of the Northumberland - Solway Basin. The fluvial systems appear to be integral components of the palaeoenvironment (Bennett et al. 2016), and no valley systems are recognized at outcrop. Lateral accretion deposits characterize some of the sandstone bodies, suggesting that meandering systems dominated, though braided systems were also present. At times, sand appears to have also been diverted by the NE extent of the Southern Uplands massif along its Midland Valley margin. However, the SW extent of these sandstone bodies is unclear, as very little sand characterizes the Ayrshire succession. Though the source of the sand is not known because no heavy mineral studies have been published yet, derivation is likely from somewhere northwards along the North Sea to the Greenland or Norway Caledonides mountains (Cliff et al. 1991; Coward 1993).

In the rest of the Midland Valley fine sand appears to have been distributed mostly by overbank flooding and small streams. In the area north of Glasgow, the small proportion of fine sand suggests that there was no significant volume of sediment supplied from the north. Late in the Tournaisian in Fife, overbank flooding and small streams supplied sediment, either from the north, or more likely from the major river system. Some alluvial fan deposits were likely localized along the northern flank of the Southern Uplands massif in Ayrshire for example (Monaghan 2004).

The intercalations of volcaniclastic rocks are localized to a small area adjacent to the NE extent of the Southern Upland massif. In the written logs, use of the terms tuff and agglomerate implies that these rocks represent primary pyroclastic deposits rather than contemporaneously resedimented ash or eroded and reworked older volcanic rocks. Such a distinction is difficult to make from the descriptions, particularly as other sedimentary lithologies form a component of some beds and could have been included as pyroclasts or through erosion of substrate material. However, the volcaniclastic beds intercalated with Ballagan facies at the top of the formation, beneath the Garleton Hills Volcanic Formation (Fig. 5), probably represents the initial explosive eruptions, or contemporaneous fluvial reworking of such deposits.

The derivation of the volcaniclastic rocks at lower levels in the formation in the East Linton and Spilmersford boreholes (Fig. 5) is enigmatic. Though basaltic volcanism preceded the Ballagan 
573 Formation in the Northumberland - Solway Basin, the only record of contemporary volcanism

574 elsewhere in northern Britain during the Tournaisian is at Heads of Ayr (Stephenson et al. 2002).

575 Thus, it seems likely that the volcaniclastic rocks in the east of the Midland Valley were eroded from 576 older outcrops, transported and re-deposited in river systems. The closest source is the Lower 577 Devonian volcanoes near Eyemouth and these may have had a more extensive outcrop at the time. 578 However, no palaeocurrent or geochemical data are available to support this inference.

4.2.6. Marine flooding. The sporadic occurrences in the succession of this area yielding 580 low diversity marine taxa suggest cryptic marine events. Bennett et al. (2017) clearly demonstrated 581 that such intervals were abundant in the Tweed Basin from the presence of 128 beds containing single tier colonizations of Chondrites in the $500 \mathrm{~m}$ thick succession of the Norham Borehole. They attributed emplacement of the burrowing fauna to storm surges.

The marine taxa seen in the western part of the Midland Valley include Cardiomorpha and brachiopods such as Lingula, which are not seen in the Tweed Basin and Fife. This suggests that their marine connections were from different directions; their emplacement may represent true marine transgressions, rather than surges. A pathway from Ayrshire to the SW is likely, on the grounds that brachiopods are recorded from the coeval and sedimentologically similar Ballycultra Formation in Northern Ireland (Griffith \& Wilson 1982). The Tweed Basin is, by contrast, much closer to the more marine Northumberland - Solway Basin and here the storm surges could have been funnelled inland along drowned river systems. The presence of two marine intervals near the top of the East Dron succession is more difficult to understand, though here again access could have been via the same route and these two events probably represent the most energetic storms seen.

\subsection{Marginal marine Northumberland - Solway Basin.}

A narrow coastal floodplain existed along the southern margin of the Southern Uplands massif (Leeder 1974b). The basalt lavas of the Birrenswark Volcanic Formation were buried beneath fluvial sands of the Whita Sandstone Member at the base of the Ballagan Formation. The sandstone unit comprises up to 500 m of massive and cross-bedded, fine to coarse-grained sandstone in typically fining upwards units up to 6 m thick (Lumsden et al. 1967; Leeder 1974b). It is clean, carbonate cemented and without the characteristic micaceous and carbonaceous partings of most other Ballagan sandstones. Leeder (1974b) interpreted these as fluvial channel deposits derived from the Southern Uplands massif. Floodplain siltstones and thin dolostones are interbedded with the Whita sandstone units, but there are very few palaeosols. Surface exposures reveal little evidence of evaporite deposits in this belt, with the exception of the Hoddom Borehole, near Ecclefechan, which 
605

606

607

608

609

610

611

612

613

614

615

616

617

618

619

620

621

622

623

624

625

626

627

628

629

630

631

632

633

634

635

636

proved abundant layers and nodules of gypsum deposited in a perennial brine pan (Millward et al. 2018).

To the SW, bordering the Solway Firth, Maguire et al. (1996) interpreted early Mississippian environments. Coarsely clastic alluvial fan deposits built up adjacent to the active syn-depositional Solway - Gilnockie faults marking the southern margin of the Southern Uplands massif and were bordered by low relief coastal plains. Prograding deltas, supplied with sediment along the axis of the basin, along with lime muds and storm emplaced sheet sands were deposited in a shallow offshore region. Biostratigraphical control on some of the sections in this area is poor and only some of these rocks may be Tournaisian in age.

Sherwin (2018) described mixed marginal marine and vegetated floodplain environments with vertebrate remains from three sites along the northern edge of the basin that further illustrate the proximity and migration of contemporary coastlines. The succession in Whitrope Burn [NY 507 965], near Langholm comprises carbonate rocks, deposited by high density turbidity currents into a sheltered lagoon (Richards et al. in press). Some beds contain an abundant and diverse assemblage of shark teeth. At Coldstream (Fig. 1), and in the River Coquet, south of the Cheviot massif, shallow marine carbonate, coarsening-upward bay-fill, and near-shore facies assemblages are intercalated with a vegetated floodplain facies assemblage.

Further southward toward the basin depocentre, there is increasing evidence of marine conditions, which are characteristic of the Lyne Formation. There are coarsening upward siltstone to fine sandstone units, interpreted as bay fills (Leeder 1974b). The dolostones are replaced by carbonate rocks, some including stromatolitic bioherms and oncolite beds, whereas others contain an abundant and diverse marine fauna including crinoids, foraminifera and brachiopods (Fig. 10; Leeder 1975a, b; Brand 2018).

In the centre of the Northumberland-Solway Basin, $1153 \mathrm{~m}$ of anhydrite-bearing carbonate rocks and mudstone within the Lyne Formation were proved in the Easton No 1 well, north of Carlisle (Fig. 1; Ward 1997). The uppermost part of the evaporite succession is upper Chadian lower Arundian (Ward 1997), but the age of the lower part is not well constrained biostratigraphically and may be of Tournaisian age. The succession contains about 120 anhydrite beds ranging from $30 \mathrm{~cm}$ to $7.9 \mathrm{~m}$ thick with some of the thickest evaporite units in the lower part. The subsurface extent of these evaporites mapped by Ward (1997) may extend eastwards to the Newcastle area. Sulphate deposits cementing Permian breccias along the Ninety-Fathom Fault and from brines encountered in the local collieries (Younger et al. 2016) may have been derived from 
637 this deep source. Ward (1997) suggested that the evaporites were deposited in salinas, but the

638 thickness and association with carbonate rocks suggests a restricted marine environment.

\section{5. Discussion}

640 The facies change at the base of the Ballagan Formation signals a profound change in the 641 paleoenvironments along this part of the southern margin of Laurussia. The upper Devonian 642 Kinnesswood Formation represents braided or meandering river channels filling several small 643 depocentres in the Midland Valley (Read et al. 2002), while in southern Scotland rivers fed sediment 644 from the catchments into an elongate, north-eastwards orientated endorheic basin (Leeder 1976). 645 Throughout, calcrete-bearing palaeosols developed on stable alluvial terraces in a semi-arid seasonal 646 climate (Burgess 1961; Leeder 1976; Wright et al. 1993). In late Famennian times (Marshall et al. this 647 volume), basalt lava and pyroclastic rocks were erupted from volcanoes during rapid extension along 648 the northern margin of the Northumberland - Solway Basin. The change to a wetland regime was 649 likely brought about by a combination of events related to the juxtaposition of Gondwana and 650 Laurussia causing fragmentation of the continental margin and opening of strike-slip basins through 651 the region, and to climate change (Coward 1993; Falcon-Lang 1999; Domeier \& Torsvik 2014). 652 Contemporary faulting played a significant role in the particularly thick accumulation of Tournaisian 653 to Chadian strata in the Northumberland - Solway Basin (Chadwick et al. 1995). Subsidence related 654 to the major faults bounding the Southern Uplands is inferred from the presence of alluvial fan 655 deposits, and at Dunbar, for example by local thickening of the flood-plain sedimentary rocks toward 656 the fault. emerged from recent studies of the Norham cores and the coastal section at Burnmouth by Bennett et al. (2016, 2017), Kearsey et al. (2016) and Millward et al. (2018) across the Tweed and Midland

660 Valley basins. The spatially and temporally diverse set of palaeoenvironments defines a tropical, 661 strongly seasonal, coastal wetland with very low relief landscape, developed in the hinterland of an 662 archipelago of more elevated landmasses. Abundant fresh to brackish water, saline and hypersaline 663 floodplain lakes co-existed on the floodplain. Evaporation of some of the closed saline and 664 hypersaline lakes during the dry season, or drier intervals formed sabkhas. Microbial mats were 665 associated with these areas (Millward et al. 2018). A persistent, dominantly meandering, fluvial system in the east of the region hosts the greatest diversity of terrestrial habitats with the riparian strip extensively vegetated as indicated by a diverse suite of palaeosols ranging from ephemeral plant colonies to marsh and forest (Retallack \& Dilcher 1988; Kearsey et al. 2016). Forest habitats 
670

671

672

673

674

675

676

677

678

679

680

681

682

683

684

685

686

687

688

689

690

691

692

693

694

695

696

697

698

699

700

the true extent of such habitats is poorly known because of low confidence in the interpretation of palaeosols in the archived borehole data. Other areas were dominated by perennial floodplain lakes. By contrast, rainfall, overbank and marine flooding distributed sediment across the floodplain during the wet season, forming and recharging lakes (Bennett et al. 2016, 2017). The large lateral extents reached during the storm surges suggest that the floodplain had very low relief and was only just above sea level.

High rainfall during tropical storms likely formed many of the floodplain lakes. However, storm surges caused marine flooding from the SW and northward into the east of the region, reaching significant parts of the Midland Valley and at times as far north as Fife and Tayside, some $140 \mathrm{~km}$ due north of the nearest likely coastline. Are such distances supported from modern examples? Williams (2009) and Goodbred \& Hine (1995) documented the transport by storm surges of sediment containing sporadic marine fossils inland from the Louisiana and Florida coasts respectively for distances up to $6 \mathrm{~km}$. However, far greater distances have been recorded occasionally. The storm surge associated with the category 1 hurricane Isaac in Louisiana in 2012 caused the Mississippi river to flow upstream for a distance of 480 river kilometres and at about two-thirds of this distance the river level was still $2.6 \mathrm{~m}$ above normal (Berg 2012). Substantial areas were flooded to depths up to $5 \mathrm{~m}$, though the deepest water was recorded adjacent to man-made levees.

Another factor may have contributed to the extensive existence of saline and hypersaline lakes. Evaporation in the coastal lagoons and marshes during the dry season may have initiated the upstream flow of saline water when there is low fresh water runoff. This was demonstrated for example by Barusseau et al. (1985) to occur in the Salum and Gambia rivers of West Africa. There the effects of a 'salinity tide' and increasing salinity inland are seen up-river for up to $250 \mathrm{~km}$.

Many equatorial coastal zones, for example around the Gulf of Mexico, in Florida and Ghana, are barred with barrier islands protecting lagoons. Breaching of the barriers during tropical storms can increase the flooded area hugely and this could have been a further mechanism of flooding the Ballagan wetlands. However, barrier island deposits have low preservation potential and their recognition in the geological record is difficult. Sherwin (2018) considered the possibility of such an origin for a succession of planar bedded, wave-rippled sandstones in Coquetdale, though these rocks overlie floodplain strata and were more likely to have represented transgression, establishing more open bay conditions. 

changed from time to time, probably instigated by river flooding events, the coastal wetland regime remained remarkably constant for the duration of the Tournaisian, a period of at least 12 million years. The succession is aggradational, in which a delicate balance was maintained between subsidence, compaction and sedimentation rates to keep the floodplain just above sea level. Few hiatuses in the succession are seen and are mostly evident in erosive channels at the base of fluvial sandstone units. Another exception is the floodplain terraces represented in the succession at Eastern Hole near Pease Bay on the NE margin of the Southern Uplands massif where the formation is substantially thinner than in nearby areas (Andrews et al. 1991). Preservation of delicate desiccated and cracked surfaces (Bennett et al. 2016; Kearsey et al. 2016), and abundant palaeosols testify to continued 'passive' burial of the floodplain. Time gaps of centuries to thousands of years are mostly evident in the substantial number of vertisols that are seen in the upper part of the succession in the Norham Borehole and at Burnmouth (Kearsey et al. 2016).

Johnson (1982) likened the landscape of northern England during Mississippian times to that of the Gulf Coast plain of SE USA today. However, the picture that has emerged during Tournaisian times is not of a floodplain associated with a major delta system. That scenario was initiated in Arundian times with the onset of the Fell Sandstone fluvial distributive system and the overlying Yoredale facies (Kearsey et al. 2018). Modern analogues for the Ballagan Formation appear to be few, despite an extensive search.

The Everglades of southern Florida demonstrate some aspects in common. This area has a seasonal climate and is frequently inundated by tropical storms. Freshwater and brackish lakes and marshes are abundant; palustrine carbonates and peats are accumulating; and desiccation features and pedogenic overprinting are widespread (Platt \& Wright 1992). These give way at the coast to marginal marine conditions, and offshore in the Bahamas, gypsum precipitates within the carbonate system (Glunk et al. 2011).

The seasonal wetlands of the Pantanal of Brazil in South America has a precipitation rate of about $1100 \mathrm{~mm}$ per year, similar to that estimated for the Ballagan Formation by Kearsey et al. (2016); during the wet season the wetland is flooded through the major rivers (Costa et al. 2015). The landscape is gently undulating with variations in elevation of up to $5 \mathrm{~m}$, but the overall gradient across the region is less than $1 \%$. A major feature of the southern part of the region is the juxtaposition on the floodplain of round to elongate freshwater and saline lakes; the latter are locally concentrated. Typically, the saline lakes have surface areas of less than $0.15 \mathrm{~km}^{2}$ and are at a slightly lower elevation than the freshwater lakes covering areas of up to $0.8 \mathrm{~km}^{2}$ (Costa et al. 2015). 
The $\mathrm{pH}$ of the saline lakes is greater than 9 and, though carbonate minerals are precipitated, the lakes never dry out and gypsum or halite is unknown. Seasonal drainage channels provide connections between the lakes and rivers and the intervening areas are covered in forest or open, mainly herbaceous, cover vegetation.

The vast expanse of the northern Great Plains of western Canada is characterized by undulating topography and hosts many hyposaline to hypersaline and alkaline lakes with surface areas that vary from a few tens of metres across to the immense Lake Manitoba (Last \& Slezak 1988). Some of the hypersaline lakes are meromictic; carbonate sediment accumulation is common with gypsum and other evaporitic salts in some. Large rivers traverse the region and there are many regions of endorheic drainage. The climate is cold and semi-arid.

Comparative examples in the geological record are sparse too. The lower Cretaceous Leza Formation of the Cameros Basin in NE Spain contains evidence for a coastal wetland setting, with a low diversity biota, terrestrial sediments with a range of edaphic features, lacustrine environments from freshwater to hypersaline, and leading into a transition to the marine environment; alluvial fans fed clastic detritus into some lakes (Suarez-Gonzalez et al. 2015).

The Late Miocene Solimoes Formation in the Amazon Basin comprises a thick vertebratebearing succession of typically red or blue-grey, fine-grained sandstones and mudstones (Latrubesse et al. 2010). The sandstones are stacked river-channel deposits of avulsive Andean megafans and floodplain distributaries. The mudstones are lacustrine and floodplain deposits with pedogenic layers, abundant desiccation cracks and some gypsum veins. Latrubesse et al. (2010) interpreted the succession as an extensive wetland that lay between the Andes and the Purus Arch, prior to development of the current Amazon River system.

Fluvial and lacustrine environments are intercalated in the Miocene Siwalik Group in northern Pakistan. Laminated siltstones, decimetres to several metres thick, were deposited in lakes estimated to have water depths of no more than $14 \mathrm{~m}$ and many less than $10 \mathrm{~m}$; the lakes were from a few hundred metres to $25 \mathrm{~km}$ across (Zaleha 1997). Desiccation cracks are common and siltstone beds typically overlie palaeosols. Units of very fine- to medium-grained sandstone are generally 5$10 \mathrm{~m}$ thick, though some exceed $100 \mathrm{~m}$ and comprise up to 10 storeys. The sedimentary characteristics indicate these to be river-channel deposits. Thin sandstone beds intercalated with mudstone are thought to have been deposited from non-channelized and channelized flows during flood episodes (Zaleha 1997). 
None of these examples is a particularly good fit for the early Mississippian Ballagan palaeoenvironments. The Northern Great Plains, Pantanal, Siwalik Group and Solimoes Formation are all located in tectonic settings different from that of the Ballagan Formation. A coastal setting with transition to marginal marine is present only in the Everglades and the Leza Formation. Tropical seasonal climates are present in the Siwalik Group, Pantanal and the Everglades. However, none of these successions hosts evaporites in abundance comparable with the Ballagan Formation. Primary dolostones are absent from all, though palustrine carbonates are a characteristic of the Everglades. However, the Great Plains, Siwalik Group and Solimoes Formation are examples of the association of lacustrine and fluvial systems. Furthermore, lakes of various salinities characterize both the Great Plains and Pantanal regions. The Leza Formation has perhaps the best range of comparable palaeoenvironments, though the wetland was small, estimated to have been about $10 \times 30 \mathrm{~km}$, was not equatorial and evaporites are a minor component; though alluvial fans fed sediment into lakes, established fluvial systems were absent. These examples serve to illustrate the unusual nature of the Ballagan wetlands.

\section{Conclusions}

780 The Ballagan Formation is an unusual example in the geological record of a succession with 781 abundant lacustrine deposits of various scales and salinities, interspersed with fluvial and evaporitic 782 facies within a tropical, seasonal, coastal wetland palaeoenvironmental setting. It has few parallels in the literature, particularly with the abundance of small-scale evaporite deposits. An extensive, very low-relief coastal wetland developed along the equatorial southern continental margin of Laurussia and lasted for the 12 million years of the Tournaisian. The Midland Valley and Tweed basins were separated from the marginal marine seaway of the Northumberland - Solway Basin to the south by an archipelago of upland areas.

The new palaeogeographical map constructed from borehole and outcrop data across the Midland Valley and Tweed Basin shows the juxtaposition of a mosaic of sedimentary environments from fresh and brackish to saline and hypersaline lakes, a diverse suite of floodplain palaeosols and a persistent fluvial system in the east of the region. The strongly seasonal climate led to episodic flooding, both meteoric and marine, the latter driven from the SW into both the western Midland Valley and Northumberland - Solway Basin; marine flooding also reached the Tweed Basin and Tayside in the east via the river floodplain. The sedimentary environments and palaeosol types indicate a broad mosaic of different terrestrial and aquatic habitats that hosted a diverse vertebrate fauna that included tetrapods which had, for the first time, terrestrial capability. The areal size of the region is comparable to that of coastal wetlands today, such as the Everglades of southern Florida. 


\section{Acknowledgements}

This research formed part of the TW:eed Project (Tetrapod World: early evolution and diversification), led by Jenny Clack (University Museum of Zoology, Cambridge) and funded by N.E.R.C. consortium grants to the British Geological Survey (NE/J021067/1) and the Universities of Leicester (NE/J020729/1) and Southampton (NE/J021091/1). The authors are grateful for the helpful comments of two anonymous referees. DM, PJB, TIK and MAEB publish with the permission of the Executive Director, British Geological Survey (N.E.R.C.).

\section{REFERENCES}

Alonso-Zarza, A. M. 2003. Palaeoenvironmental significance of palustrine carbonates and calcretes in the geological record. Earth-Science Reviews 60, 261-298.

Anderson, J. S., Smithson, T., Mansky, C. F., Meyer, T. \& Clack, J. 2015. A diverse tetrapod fauna at the base of 'Romer's Gap'. PLOS ONE, 10, 1-27.

Anderton, R. 1985. Sedimentology of the Dinantian of Foulden, Berwickshire, Scotland. Transactions of the Royal Society of Edinburgh: Earth Sciences 76, 7-12.

Andrews, J. E. \& Nabi, G. 1994. Lithostratigraphy of the Dinantian Inverclyde and Strathclyde Groups, Cockburnspath Outlier, East Lothian-North Berwickshire. Scottish Journal of Geology 30, 105-119.

Andrews, J. E. \& Nabi, G. 1998. Palaeoclimatic significance of calcretes in the Dinantian of the Cockburnspath Outlier (East Lothian-North Berwickshire). Scottish Journal of Geology 34, 153-164.

Andrews, J. E., Turner, M. S., Nabi, G. \& Spiro, B. 1991. The anatomy of an early Dinantian terraced floodplain: palaeo-environment and early diagenesis. Sedimentology 38, 271-287.

Andrews, S. M. 1985. Rhizodont crossopterygian fish from the Dinantian of Foulden, Berwickshire, Scotland, with a re-evaluation of this group. Transactions of the Royal Society of Edinburgh: Earth Sciences 76, 67-95

Arsenikos, S., Quinn, M. F., Kimbell, G., Williamson, P., Pharaoh, T., Leslie, G. \& Monaghan, A. A. 2018. Structural development of the Devono-Carboniferous plays of the UK North Sea. In Monaghan, A. A., Underhill, J. R., Hewett, A. J. \& Marshall, J. E. A. (eds) Paleozoic plays of NW Europe Geological Society of London Special Publication 471. https://doi.org/10.1144/SP471.3

Bateman, R. M. \& Scott, A. C. 1990. A reappraisal of the Dinantian floras at Oxroad Bay, East Lothian, Scotland. 2. Volcanicity, palaeoenvironments and palaeoecology. Transactions of the Royal Society of Edinburgh: Earth Sciences 81, 161-194.

Belt, E. S., Freshney, E. C. \& Read, W. A. 1967. Sedimentology of Carboniferous cementstone facies, British Isles and Eastern Canada. The Journal of Geology 75, 711-721.

Bennett, C. E., Williams, M., Leng, M. J., Siveter, D. J., Davies, S. J., Sloane, H. J. \& Wilkinson, I. P. 2011. Diagenesis of fossil ostracods: implications for stable isotope based palaeoenvironmental reconstruction. Palaeogeography, Palaeoclimatology, Palaeoecology 305, 150-161. 
Bennett, C. E., Kearsey, T. I., Davies, S. J., Millward, D., Clack, J. A., Smithson, T. R. \& Marshall, J. E. A. 2016. Early Mississippian sandy siltstones preserve rare vertebrate fossils in seasonal flooding episodes. Sedimentology 63, 1677-1700.

Bennett, C. E., Howard, A. S., Davies, S. J., Kearsey, T. I., Millward, D., Brand, P. J., Browne, M. A. E. Reeves, E. J. \& Marshall, J. E. A. 2017. Ichnofauna record cryptic marine incursions onto a coastal floodplain at a key early Mississippian tetrapod site. Palaeogeography, Palaeoclimatology, Palaeoecology 468, 287-300.

Berg, R. 2012. Tropical Cyclone Report: Hurricane Isaac (AL092012). National Hurricane Center, 78 pp. www.nhc.noaa.gov

Brand, P. J. 2018. A list of fossil specimens in the BGS biostratigraphy collections from the Ballagan Formation in Scotland and from the former Lower Border Group of the Northumberland-Solway Basin. British Geological Survey Internal Report IR/18/03.

Browne, M. A. E. 1980. The Upper Devonian and Lower Carboniferous (Dinantian) of the Firth of Tay, Scotland. Institute of Geological Sciences Report series 80/9.

Browne, M. A. E., Dean, M. T., Hall, I. H. S., McAdam, A. D., Monro, S. K. \& Chisholm, J. I. 1999. A lithostratigraphical framework for the Carboniferous rocks of the Midland Valley of Scotland. British Geological Survey Research Report RR/99/07.

Burgess, I. C. 1961. The fossil soils of the Upper Old Red Sandstone of South Ayrshire. Transactions of the Geological Society of Glasgow 24, 138-153.

Burgess, I. C. \& Holliday, D. W. 1979. Geology of the country around Brough-under-Stainmore. Memoir of the Geological Survey of Great Britain, sheets 31 and parts of sheets 25 and 30, England and Wales $131 \mathrm{pp}$. London: HMSO.

Carpenter, D. K., Falcon-Lang, H. J., Benton, M. J. \& Henderson, E. 2015. Carboniferous (Tournaisian) fish assemblages from the Isle of Bute, Scotland: systematics and palaeoecology. Palaeontology 57, 1215-1240.

Carruthers, R. G., Burnett, G. A. \& Anderson, W. 1932. The geology of the Cheviot Hills. Memoir of the Geological Survey England \& Wales, explanation of sheets 3 \& 5.174 pp. London: HMSO.

Cater, J. M. L., Briggs, D. E. G. \& Clarkson, E. N. K. 1989. Shrimp-bearing sedimentary successions in the Lower Carboniferous (Dinantian) Cementstone and Oil Shale groups of northern Britain. Transactions of the Royal Society of Edinburgh: Earth Sciences 80, 5-15.

Chadwick, R. A., Holliday, D. W., Holloway, S. \& Hulbert, A. G. 1995. The structure and evolution of the Northumberland-Solway Basin and adjacent areas. Subsurface memoir of the British Geological Survey. 90 pp. London: HMSO.

Chisholm, J. I. \& Dean J. M. 1974. The Upper Old Red Sandstone of Fife and Kinross: a fluviatile sequence with evidence of marine incursion. Scottish Journal of Geology 10, 1-30. 
869 Chisholm, J. I., McAdam, A. D. \& Brand, P. J. 1989. Lithostratigraphical classification of Upper

870 Devonian and Lower Carboniferous rocks in the Lothians. British Geological Survey Technical Report

871 WA/89/26, $31 \mathrm{pp}$.

872 Clack, J. A. 2002. An early tetrapod from 'Romer's Gap'. Nature 418, 72-76.

873 Clack, J. A. \& Finney, S. M. 2005. Pederpes finneyae, an articulated tetrapod from the Tournaisian of 874 western Scotland. Journal of Systematic Palaeontology 2, 311-346.

875 Clack, J. A., Bennett, C. E., Carpenter, D. K., Davies, S. J., Fraser, N. C., Kearsey, T. I., Marshall, J. E. A., 876 Millward, D., Otoo, B. K. A., Reeves, E. J., Ross, A. J., Ruta, M., Smithson, K. Z., Smithson, T. R. \& 877 Walsh, S.A. 2016. Phylogenetic and environmental context of a Tournaisian tetrapod fauna. Nature 878 Ecology and Evolution 1, 11 pp.

879 Clarkson, E. N. K. 1985. Palaeoecology of the Dinantian of Foulden, Berwickshire, Scotland.

880 Transactions of the Royal Society of Edinburgh: Earth Sciences 76, 97-100.

881 Clayton, G. 1986. Late Tournaisian miospores from the Ballycultra Formation at Cultra, County Down, Northern Ireland. Irish Journal of Earth Sciences 8, 73-79.

883 Clayton, G., Graham, J. R., Higgs, K., Sevastopulo, G. D. \& Welsh, A. 1986. Late Devonian and early 884 Carboniferous palaeogeography of southern Ireland and southwest Britain. Annales de la Société 885 géologique de Belgique 109, 103-111.

886 Clayton, G. \& Higgs, K. 1979. The Tournaisian marine transgression in Ireland. Journal of Earth 887 Sciences, Royal Dublin Society 2, 1-10.

888 Cliff, R. A., Drewery, S. E. \& Leeder, M. R. 1991. Sourcelands for the Carboniferous Pennine river 889 system: constraints from sedimentary evidence and U-Pb geochronology using zircon and monazite. 890 In Morton, A. C., Todd, S. P. \& Haughton, P. D. W. (eds) Developments in Sedimentary Provenance 891 Studies. Geological Society of London Special Publication 57, 137-159.

892 Clough, C. T., Barrow, G., Crampton, C. B., Maufe, H. B., Bailey, E. B. \& Anderson, E. M. 1910. The 893 Geology of East Lothian, including the counties of Edinburgh and Berwick. Memoir of the Geological 894 Survey of Scotland, Explanation of sheet 33 with parts of 34 and 41. $2^{\text {nd }}$ edition. 226 pp. Edinburgh: 895 HMSO.

896 Cope, J. C. W., Guion, P. D., Sevastopulo, G. D. \& Swan, A. R. H. 1992. Carboniferous In Cope, J. C. W., 897 Ingham, J. K. \& Rawson, P. F. (eds) Atlas of palaeogeography and lithofacies. Geological Society, 898 London, Memoir 13, 67-86.

899 Costa, M., Telmer, K. H., Evans, T. L., Almeida, T. IR. \& Diakun, M. T. 2015. The lakes of the Pantanal: 900 inventory, distribution, geochemistry, and surrounding landscape. Wetlands Ecology and 901 Management 23, 19-39.

902 Coward, M. P. 1993. The effect of Late Caledonian and Variscan continental escape tectonics on 903 basement structure, Paleozoic basin kinematics and subsequent Mesozoic basin development in NW 904 Europe. Geological Society of London Petroleum Geology Conference 4, 1095-1108. 
905

906

907

908

909

910

911

912

913

914

915

916

917

918

919

920

921

922

923

924

925

926

927

928

929

930

931

932

933

934

935

936

937

938

939

Davies, A. 1970. Carboniferous rocks of the Sanquhar outlier. Geological Survey of Great Britain Bulletin 31, 37-87.

Davies, A., McAdam, A. D. \& Cameron, I. B. 1986. Geology of the Dunbar district. Memoir of the British Geological Survey, Sheet 33E and part of 41(Scotland). 69 pp. London: HMSO.

Day, J. B. W. 1970. Geology of the country around Bewcastle. Memoir Geological Survey, Great Britain, England and Wales Sheet 12. 357 pp. London: HMSO.

Dean, M. T., Browne, M. A. E., Waters, C. N., \& Powell, J. H. 2011. A lithostratigraphical framework for the Carboniferous rocks of northern Great Britain (onshore). British Geological Survey Research Report, RR/10/07, $165 \mathrm{pp}$.

Domeier, M. \& Torsvik, T. H. 2014. Plate tectonics in the late Paleozoic. Geoscience Frontiers 5, 303350.

Etthenson, F. R., Dever Jr., G. R. \& Grow, J. S. 1988. A paleosol interpretation for profiles exhibiting subaerial exposure "crusts" from the Mississippian of the Appalachian Basin. In Reinhart, J. \& Sigleo, W.R. (eds) Paleosols and weathering through geologic time. Geological Society of America Special Paper 216, 49-79.

Eyles, V. A., Simpson, J. B. \& MacGregor A. G. 1949. Geology of Central Ayrshire. Memoir Geological Survey, Scotland (sheet 14). $2^{\text {nd }}$ edition. 160 pp. Edinburgh: HMSO.

Falcon-Lang, H.J. 1999. The Early Carboniferous (Courceyan-Arundian) monsoonal climate of the British Isles: evidence from growth rings in fossil woods. Geological Magazine 136, 177-187.

Francis, E. H., Forsyth, I. H. Read, W. A. \& Armstrong, M. 1970. The geology of the Stirling district. Memoir Geological Survey, Scotland (sheet 39). 357 pp. Edinburgh: HMSO.

Gardiner, B. G. 1985. Actinopterygian fish from the Dinantian of Foulden, Berwickshire, Scotland. Transactions of the Royal Society of Edinburgh: Earth Sciences 76, 61-66.

Glunk, C., Dupraz, C., Braissant, O., Gallagher, K. L., Verrecchia, E. P. \& Visscher, P. T. 2011. Microbially mediated carbonate precipitation in a hypersaline lake, Big Pond (Eleuthera, Bahamas). Sedimentology 58, 720-738.

Goodbred, S. L. \& Hine, A. C. 1995. Coastal storm deposition: salt-marsh response to a severe extratropical storm, March 1993, west-Central Florida. Geology 23, 679-682.

Greig, D. C. 1988. Geology of the Eyemouth district. Memoir British Geological Survey, Scotland sheet 34. 78 pp. London: HMSO.

Griffith, A.E. \& Wilson, H.E. (1982) Geology of the country around Carrickfergus and Bangor. Memoir Geological Survey Northern Ireland (sheet 29). 118 pp. HMSO, Belfast.

Gueriau, P., Rabet, N., Clement, G., Lagebro, L., Vannier, J., Briggs, D. E. G., Charbonnier, S., Olive, S. \& Berthoux, O. 2016. A 365-million-year-old freshwater community reveals morphological and ecological stasis in Branchiopod crustaceans. Current Biology 26, 383-390. 
940 Johnson, G. A. L. 1982. Geographical change in Britain during the Carboniferous Period. Proceedings

941 of the Yorkshire Geological Society 44, 181-203.

942 Kaiser, S. I., Aretz, M. \& Becker, R. T. 2015. The global Hangenberg Crisis (Devonian-Carboniferous

943 transition): review of a first-order mass extinction. In Becker, R. T. Königshof P.\& Brett C. E. (eds)

944 Devonian Climate, Sea Level and Evolutionary Events Geological Society of London Special

945 Publication 423, 423-429.

946 Kearsey, T., Millward, D., Ellen, R., Whitbread, K. \& Monaghan, A. A. 2018. Revised stratigraphic

947 framework of pre-Westphalian Carboniferous petroleum system elements from the Outer Moray

948 Firth to the Silverpit Basin, North Sea, UK. In Monaghan, A. A., Underhill, J. R., Hewett, A. J. \&

949 Marshall, J. E. A. (eds) Paleozoic plays of NW Europe Geological Society of London Special Publication

950 471. https://doi.org/10.1144/SP471.11

951 Kearsey, T. I., Bennett, C. E., Millward, D., Davies, S. J., Gowing, C. J. B., Kemp, S. J., Leng, M. J.,

952 Marshall, J. E. A., \& Browne, M. A. E. 2016. The terrestrial landscapes of tetrapod evolution in

953 earliest Carboniferous seasonal wetlands of S.E. Scotland. Palaeogeography, Palaeoclimatology,

954 Palaeoecology 457, 52-69.

955 Last, W. M. \& Slezak, L. A. 1988. The salt lakes of western Canada: a paleolimnological overview.

956 Hydrobiologia 158, 301-316.

957 Latrubesse, E. M., Cozzuol, M., da Silva-Caminha, S. A. F., Rigsby, C. A., Absy, M. L. \& Jaramillo, C.

958 2010. The Late Miocene paleogeography of the Amazon Basin and the evolution of the Amazon River

959 system. Earth-Science Reviews 99, 99-124.

960 Leeder, M. R. 1974a. Origin of the Northumberland Basin. Scottish Journal of Geology 10, 283-296.

961 Leeder M. R. 1974b. Lower Border Group (Tournaisian) fluvio-deltaic sedimentation and

962 palaeogeography of the Northumberland Basin. Proceedings of the Yorkshire Geological Society 40,

$963 \quad 129-180$.

964 Leeder, M. R. 1975a. Lower Border Group (Tournaisian) limestones from the Northumberland Basin.

965 Scottish Journal of Geology 11, 151-167.

966 Leeder, M. R. 1975b. Lower Border Group (Tournaisian) stromatolites from the Northumberland

967 Basin. Scottish Journal of Geology 11, 207-226.

968 Leeder, M. R. 1976. Palaeogeographic significance of pedogenic carbonates in the topmost Upper

969 Old Red Sandstone of the Scottish Border Basin. Journal of Geology 11 21-28.

970 Leeder, M. R. \& Bridges P. H. 1978. Upper Old Red Sandstone near Kirkbean, Dumfries and Galloway.

971 Scottish Journal of Geology 14, 267-272.

972 Lumsden, G. I., Tulloch, W., Howells, M. F. \& Davies, A. 1967. The geology of the neighbourhood of

973 Langholm. Memoir of the Geological Survey, Scotland (Sheet 11). 255 pp. Edinburgh: HMSO.

974 McAdam, A. D. \& Tulloch, W. 1985. Geology of the Haddington district. Memoir Geological Survey of

975 Scotland, sheet 33W and part of Sheet 41.99 pp. London: HMSO. 
976 McMillan, A. A. 2002. Geology of the New Galloway and Thornhill district. Memoir of the British

977 Geological Survey, Sheets 9W and 9E (Scotland). 126pp. Norwich, UK: The Stationary Office.

978 Maguire, K., Thompson, J. \& Gowland, S. 1996. Dinantian depositional environments along the 979 northern margin of the Solway Basin, UK. In Strogen, P., Somerville, I. D. \& Jones G. LI. (eds) Recent 980 advances in Lower Carboniferous geology. Geological Society of London, Special Publication 107, $981 \quad 163-182$.

Marshall, J. E. A., Haughton, P. D. W. \& Hillier, S. J. 1994. Vitrinite reflectivity and the structure and burial history of the Old Red Sandstone of the Midland Valley of Scotland. Journal of the Geological 984 Society, London 151, 425-438.

Marshall, J. E. A., Reeves, E. J., Bennett, C. E., Davies, S. J., Kearsey, T. I., Millward, D., Smithson, T. R., \& Browne, M. A. E. 2018. Reinterpreting the age of the uppermost 'Old Red Sandstone' and Early Carboniferous in Scotland. Earth and Environmental Transactions of the Royal Society of Edinburgh, this volume.

Miller, H. 1887. The geology of the country around Otterburn and Elsdon. Memoir Geological Survey, England and Wales, sheet 8. 147 pp. London: HMSO.

Millward, D., Kearsey, T. I., \& Browne, M. A. E. 2013. Norham West Mains Farm Borehole: operations report. British Geological Survey Internal Report IR/13/033, 39 pp.

Millward, D., Davies, S. J., Williamson, F., Curtis, R., Kearsey, T. I., Bennett, C. E., Marshall, J. E. A. \& Browne, M. A. E. 2018. Early Mississippian evaporites of coastal tropical wetlands. Sedimentology. 34 pp. https://doi.org/10.1111/sed.12465

Millward, D. \& Stephenson, D. 2011. Bedrock GSI3D models from interpreted data in geologically complex Carboniferous terrains: A work in progress from the Clyde catchment area, Midland Valley of Scotland. British Geological Survey Internal Report, IR/11/052. 58 pp.

Mitchell, G. H. \& Mykura, W. 1962. The geology of the neighbourhood of Edinburgh. Memoir of the Geological Survey of Great Britain, Sheet 32, Scotland. 3rd Edition, 159 pp.

Monaghan, A. 2004. Geology of the Dailly area, Ayrshire. British Geological Survey Internal Report, IR/04/035. $24 \mathrm{pp}$.

Moy-Thomas, J. A. 1938. Carboniferous Palaeoniscids from Northumberland and Berwickshire. Geological Magazine 75, 308-318.

Nairn, A. E. M. 1958. Petrology of the Whita Sandstone, Southern Scotland. Journal of Sedimentary Petrology 28, 57-64.

1007 Neves, R., Gueinn, K. J., Clayton, G., loannides, N. S., Neville, R. S. W. \& Kruszewska, K. 1973.

1008 Palynological correlations within the Lower Carboniferous of Scotland and Northern England.

1009 Transactions of the Royal Society of Edinburgh 69, 23-70.

1010 Neves, R. \& loannides, N. 1974. Palynology of the Lower Carboniferous (Dinantian) of the 1011 Spilmersford Borehole, East Lothian, Scotland. Geological Survey of Great Britain Bulletin 45, 73-98. 
Platt, N. H. \& Wright, V. P. 1992. Palustrine carbonates and the Florida Everglades: towards an exposure index for the freshwater environment. Journal of Sedimentary Petrology 62, 1058-1071.

Purnell M. A. \& Cossey P. J. 2004. Northumberland Trough. Chapter 3 In Cossey, P. J., Adams, A. E., Purnell, M. A., Whiteley, M. J., Whyte, M. A. \& Wright, V. P. (eds) British Lower Carboniferous stratigraphy. Geological Conservation Review Series 29, Joint Nature Conservation Committee, Peterborough, 109-166.

Raymond P. E., 1946. The Genera of fossil Conchostraca, an order of bivalve Crustacea. Harvard University of Comparative Zoology Bulletin 96 (3), 218-307.

Read, W. A. \& Johnson, S. R. H. 1967. The sedimentology of sandstone formations within the Upper Old Red Sandstone and lowest Calciferous Sandstone Measures west of Stirling, Scotland. Scottish Journal of Geology 3, 242-267.

Read, W. A., Browne, M. A. E., Stephenson, D. \& Upton, B. G. J. 2002. Carboniferous. Chapter 9 In Trewin, N. H. (ed.) The Geology of Scotland. $4^{\text {th }}$ edition. The Geological Society, London, 251-299.

Retallack, G. J. \& Dilcher, D. L. 1988. Reconstructions of selected seed ferns. Annals of the Missouri Botanic Garden 75, 1010-1057.

Richards, K. R., Sherwin, J. E., Smithson, T. R., Bennion, R. F., Davies, S. J., Marshall, J. E. A. \& Clack, J. A. in press. Diverse and durophagous: early Carboniferous chondrichthyans from the Scottish Borders. Earth and Environmental Transactions of the Royal Society of Edinburgh

Scott, A. C. \& Meyer-Berthaud, B. 1985. Plants from the Dinantian of Foulden, Berwickshire, Scotland. Transactions of the Royal Society of Edinburgh: Earth Sciences 76 13-20.

Scott, W. B. 1986. Nodular carbonates in the Lower Carboniferous, Cementstone Group of the Tweed Embayment, Berwickshire: evidence for a former sulphate evaporite facies. Scottish Journal of Geology 22, 325-345.

Scrutton, C. \& Turner, B. 1995. The geology of Eyemouth and Burnmouth. Excursion 2 In Scrutton, C. (ed.) Northumbrian Rocks and Landscape: a field guide. Yorkshire Geological Society, Ellenbank Press, Maryport, 31-41.

Sherwin, J. E. 2018. In an alternating marine and non-marine depositional setting, where and how are early Carboniferous tetrapods preserved? M. Phil thesis, Univerity of Leicester.

Smith, R. A. 1986. Permo-Triassic and Dinantian rocks of the Belfast harbour Borehole. British Geological Survey Report 18, No 6.

Smithson, T. R. \& Clack, J. A. In press. A new tetrapod from Romer's Gap reveals an adaptation for walking. Earth and Environmental Transactions of the Royal Society of Edinburgh.

Smithson, T. R., Wood, S. P., Marshall, J. E. A. \& Clack, J. A. 2012. Earliest Carboniferous tetrapod and arthropod faunas from Scotland populate Romer's Gap. Proceedings of the National Academy of Science of America 109, 4532-4537. 
Smithson, T. R., Richards, K. R. \& Clack, J. A. 2016. Lungfish diversity in Romer's Gap: reaction to the end-Devonian mass extinction. Palaeontology 59, 29-44.

Stephenson, D., Bevins, R. E., Millward, D., Highton, A. J., Parsons, I., Stone, P. \& Wadsworth, W. J. 1999. Caledonian Igneous Rocks of Great Britain. Geological Conservation Review Volume 17, 648 pp. Peterborough, UK: Joint Nature Conservation Committee.

Stephenson, M. H., Williams, M., Monaghan, A. A., Arkley, S. \& Smith, R. A. 2002. Biostratigraphy and palaeoenvironments of the Ballagan Formation (Lower Carboniferous) in Ayrshire. Scottish Journal of Geology 38, 93-111.

Stephenson, M. H., Williams, M., Leng, M. J., \& Monaghan, A. A. 2004a. Aquatic plant microfossils of probable non-vascular origin from the Ballagan Formation (Lower Carboniferous), Midland Valley, Scotland. Proceedings of the Yorkshire Geological Society 55, 145-158.

Stephenson, M. H., Williams, M., Monaghan, A. A., Arkley, S., Smith, R. A., Dean, M., Browne, M. A. E. \& Leng, M. 2004b. Palynomorph and ostracod biostratigraphy of the Ballagan Formation, Midland Valley of Scotland, and elucidation of intra-Dinantian unconformities. Proceedings of the Yorkshire Geological Society 55 131-143.

Stone, P., Millward, D., Young, B., Merritt, J. W., Clarke, S. M., McCormac, M. \& Lawrence, D. J. 2010. British Regional Geology: Northern England. 5th edition. (Keyworth, Nottingham: British Geological Survey.) 294 pp.

Suarez-Gonzalez, P., Quijada, I. E., Benito, M. I. \& Mas, R. 2015. Sedimentology of ancient coastal wetlands: insights from a Cretaceous multifaceted depositional system. Journal of Sedimentary Research 85, 95-117.

Tasch, P. 1969. In Moore R. C. (ed) Treatise on Invertebrate Palaeontology, Conchostraca. Part R Arthropoda Vol. 4 (1) Crustacea (except Ostracoda) Myriopoda- Hexapoda. Lawrence, Kansas, University of Kansas and Geological Society of America.

Townsend, S. A., Boland, K. T. \& Wrigley, T. J. 1992. Factors contributing to a fish kill in the Australian wet / dry tropica. Water Research 26, 1039-1044.

Ward, J. 1997. Early Dinantian evaporites of the Easton-1 well, Solway Basin, onshore, Cumbria, England. In Meadows, N. S., Trueblood, S. P., Hardman M. \& Cowan G. (eds) Petroleum Geology of the Irish Sea and adjacent areas. Geological Society of London Special Publication 124, 277-296.

Waters, C. N., Somerville, I. D., Jones, N. S., Cleal, C. J., Collinson, J. D., Waters, R. A., Besly, B. M., Dean, M. T., Stephenson, M. H., Davies, J. R., Freshney, E. C., Jackson, D. I., Mitchell, W. I., Powell, J. H., Barclay, W. J., Browne, M. A. E., Leveridge, B. E., Long, S. L. \& McLean, D. (eds) 2011. A revised correlation of Carboniferous rocks in the British Isles. Geological Society of London Special Report 26, $186 \mathrm{pp}$.

Williams, H. F. L. 2009. Stratigraphy, sedimentology, and microfossil content of hurricane Rita storm surge deposits in Southwest Louisiana. Journal of Coastal Research 25, 1041-1051. 
Williams, M., Leng, M. J., Stephenson, M. H., Andrews, J. E., Wilkinson, I. P., Siveter, D. J., Horne, D. J. \& Vannier, J. M. C. 2006. Evidence that Early Carboniferous ostracods colonised coastal flood plain brackish water environments. Palaeogeography, Palaeoclimatology, Palaeoecology 230, 299-318.

Williams, M., Stephenson, M. H., Wilkinson, I. P., Leng, M. J. \& Miller, C. G. 2005. Early Carboniferous (Late Tournaisian-Early Viséan) ostracods from the Ballagan Formation, central Scotland, UK. Journal of Micropalaeontology 24, 77-94.

Wills, L. J. 1951. A palaeogeographical atlas of the British Isles and adjacent parts of Europe. London: Blackie and Son Ltd.

Wood, S. P. \& Rolfe, W. D. I. 1985. Introduction to the palaeontology of the Dinantian of Foulden, Berwickshire, Scotland. Transactions of the Royal Society of Edinburgh: Earth Sciences 76, 1-6.

Wright, V. P., Turner, M. S., Andrews, J. E. \& Spiro, B. 1993. Morphology and significance of supermature calcretes from the Upper Old Red Sandstone of Scotland. Journal of the Geological Society of London 150, 871-883.

Young, G. M., \& Caldwell, W. G. E. 2011. Early Carboniferous stratigraphy in the Firth of Clyde area: new information from the Isle of Bute. Scottish Journal of Geology 47, 143-156.

Young, G. M. \& Caldwell, W. G. E. 2012. The Northeast Arran Trough, the Corrie conundrum and the Highland Boundary Fault in the Firth of Clyde, SW Scotland. Geological Magazine 149, 578-589.

Younger, P. L, Manning, D. A. C., Millward, D., Busby, J. P., Jones, C. R. C. \& Gluyas, J. G. 2016. Geothermal exploration in the Fell Sandstone Formation (Mississippian) beneath the city centre of Newcastle upon Tyne, UK: the Newcastle Science Central Deep Geothermal Borehole. Quarterly Journal Engineering Geology and Hydrogeology 49, 350-363.

Zaleha, M. J. 1997. Fluvial and lacustrine palaeoenvironments of the Miocene Siwalik Group, Khaur are, northern Pakistan. Sedimentology 44, 349-368. 
Figures

1. Outcrop and subsurface map of Tournaisian rocks in the Midland Valley of Scotland, Tweed and Northumberland Solway basins. These strata include the Ballagan Formation and part of the Lyne Formation in the last basin. Major boreholes and thickness of the formation are shown. Outcrop data from the British Geological Survey DiGMapGB (C) NERC 2015; subcrop extent in the Northumberland - Solway basin from Chadwick et al. (1995).

2. Stratigraphy chart for the region (after Waters et al. 2011). KCBV Kelso, Cottonshope and Birrenswark volcanic formations; W Whita Sandstone Member. Ballagan Formation (Browne 1980) subsumes the Tyninghame Formation (Chisholm et al. 1989), Cementstone Group (Miller 1887; Greig 1988) and part of the Lower Border Group (Lumsden et al. 1967; Day 1970; Leeder 1974b). The Kinnesswood, Ballagan and Clyde Sandstone formations comprise the Inverclyde Group (Browne et al. 1999). The miospore biozones of the Ballagan Formation are from Stephenson et al. (2002, 2004a, b), Williams et al. (2005) and Smithson et al. (2012).

3. Sedimentary logs of sections drawn up from the archived BGS borehole logs to illustrate features of the facies associations. Glenrothes Borehole: flood-plain lake facies, saline and hypersaline lake facies association intercalated with overbank facies association; original written log by D. N. Halley, A. A. McMillan and M. A. E. Browne. East Linton Borehole: overbank facies association, with subordinate saline and hypersaline lake facies association; original written log by $A$. D. McAdam. Birnieknowes Borehole: fluvial facies associations, with overbank facies association and floodplain lakes; author of original written log not recorded.

4. Summary lithological logs and environmental interpretations for selected boreholes in the west and north of the Midland Valley of Scotland. Borehole locations are shown in Figure 1. The black curves within the stratigraphical columns represent the proportional thickness of grey, laminated siltstone/ mudstone per $10 \mathrm{~m}$ interval through the succession. The key to the lithology colours is given in Figure 5.

5. Summary lithological logs and environmental interpretations for selected boreholes in the east of the Midland Valley of Scotland. Borehole locations are shown in Figure 1. The miospore biozones CM, Pu and TC are from Davies et al. (1986).

6. Sedimentary logs through selected dolostone units in the Mains of Errol Member in the Glenrothes cores.

7. Histograms for key Midland Valley boreholes showing the frequency of sandstone bodies of a given thickness interval. The percentages shown for the thicker units are of the total sandstone thickness in the borehole succession.

8. Images illustrating features of the Ballagan Formation. A. Fluvial channel cut into interbedded siltstone, fine-grained sandstone and dolostone alongside the Whiteadder Water at Edington Mill [NT 894 548]. Detail in white rectangle in C. Fisherman, bottom centre, for scale; B. desiccation cracks, Dunbar shore; $C$. detail of channel side, showing multiple dislocations probably caused by collapse of the channel bank; D. Laminated dolostone, Glenrothes borehole, depth $305.65 \mathrm{~m}$; core $95 \mathrm{~mm}$ wide; E. sandy siltstone in Mains of Errol Member - dolomitized siltstone containing small dark fragments of siltstone; Glenrothes borehole, depth $358.21 \mathrm{~m}$; core $78 \mathrm{~mm}$ 
1147 diameter; F. Scan of thin section of oncolite-bearing limestone. Located at top of the formation, just 1148 beneath the Fell Sandstone, Coomsdon Burn [NY 710 038].

1149 9. Occurrence of sedimentary features and fossils recorded in selected boreholes across the 1150 east of the Midland Valley.

1151 10. Map showing the locations of fossil records from the Ballagan Formation in the BGS

1152 biostratigraphy collections. The distribution of marine taxa (see section 3.6) and 'Estheria' and Leaia 1153 (conchostracan genera) are highlighted.

1154 11. Palaeogeographic map of the Ballagan Formation.

1155

1156 


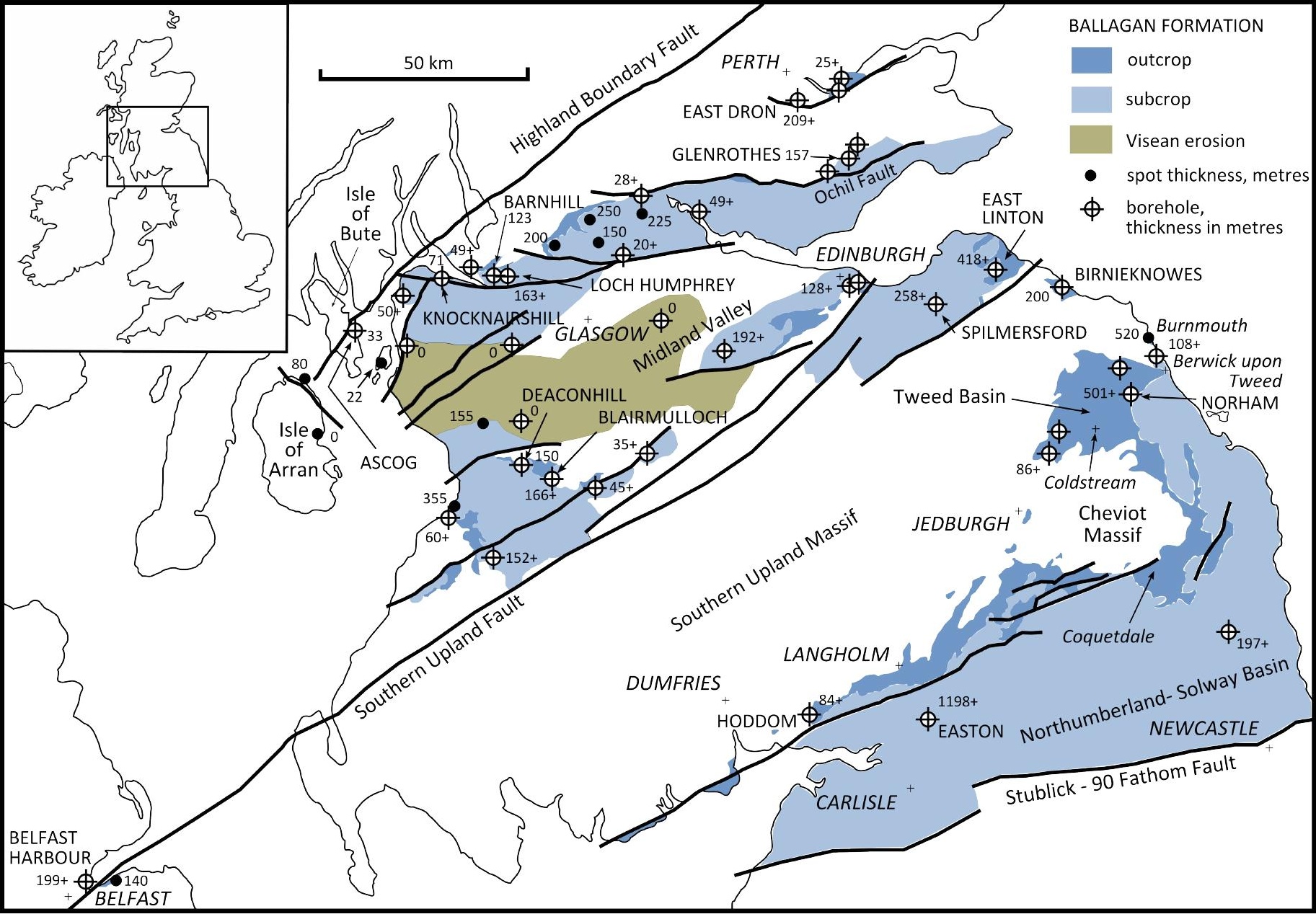




\section{Stage}

\section{Regional sub-stage}

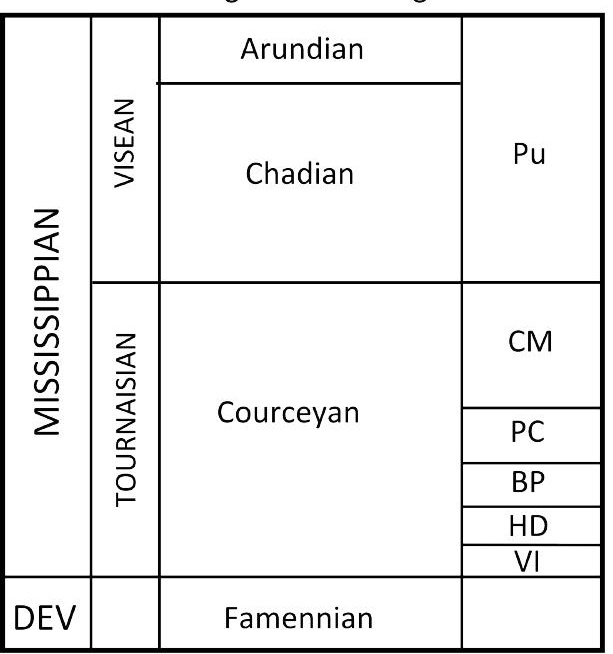

Glasgow \&

Ayrshire

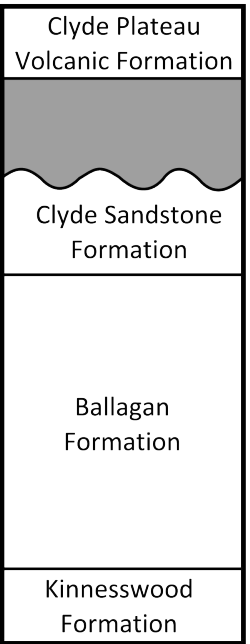

West

Lothian

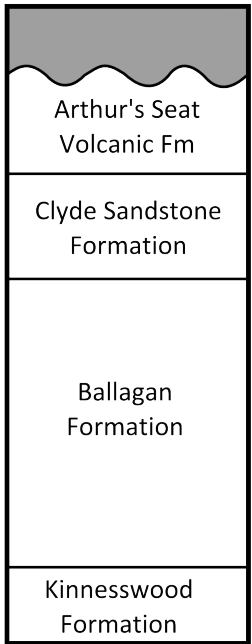

East

Lothian

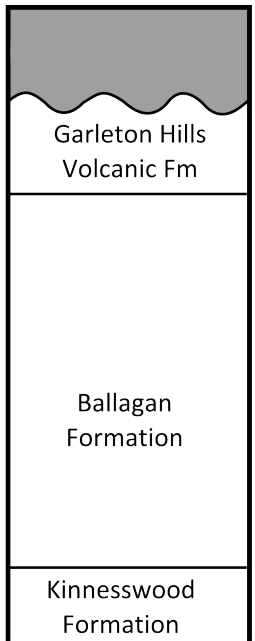

-Solway

Basin

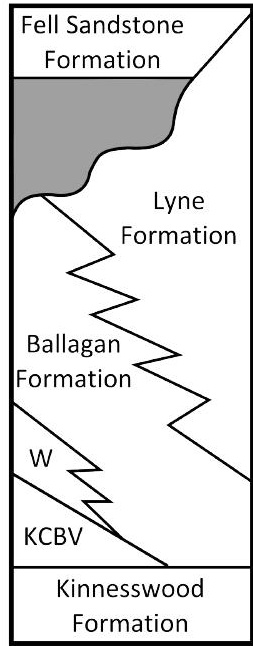


Depth
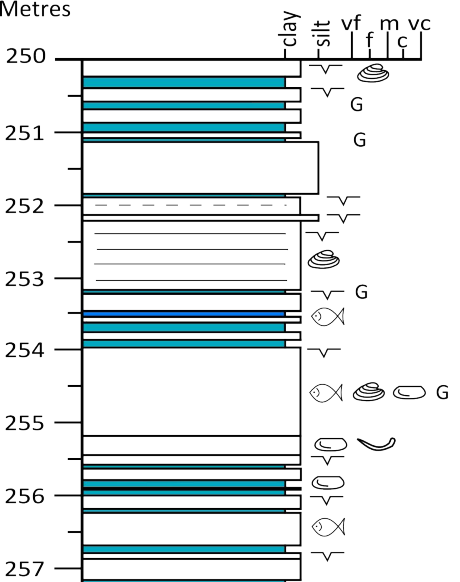

25

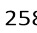

25 c

260

261

262

263

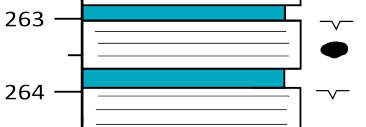

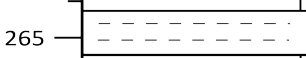

266

267

268

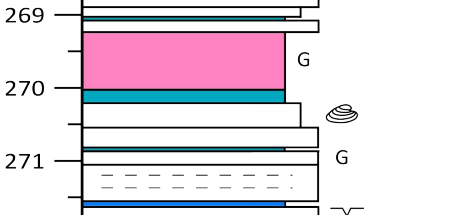

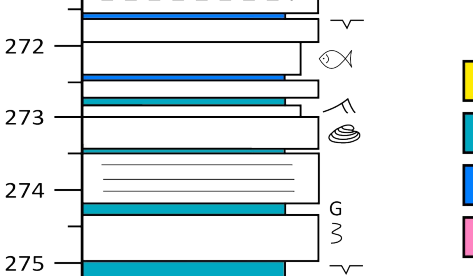

276

27
27$$
\begin{aligned}
& 27 \\
& 27
\end{aligned}
$$$$
279
$$

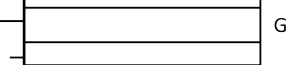

MUD SAND

Depth

Metres 离

383

384

385

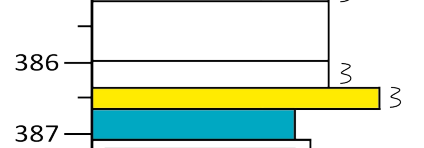

387
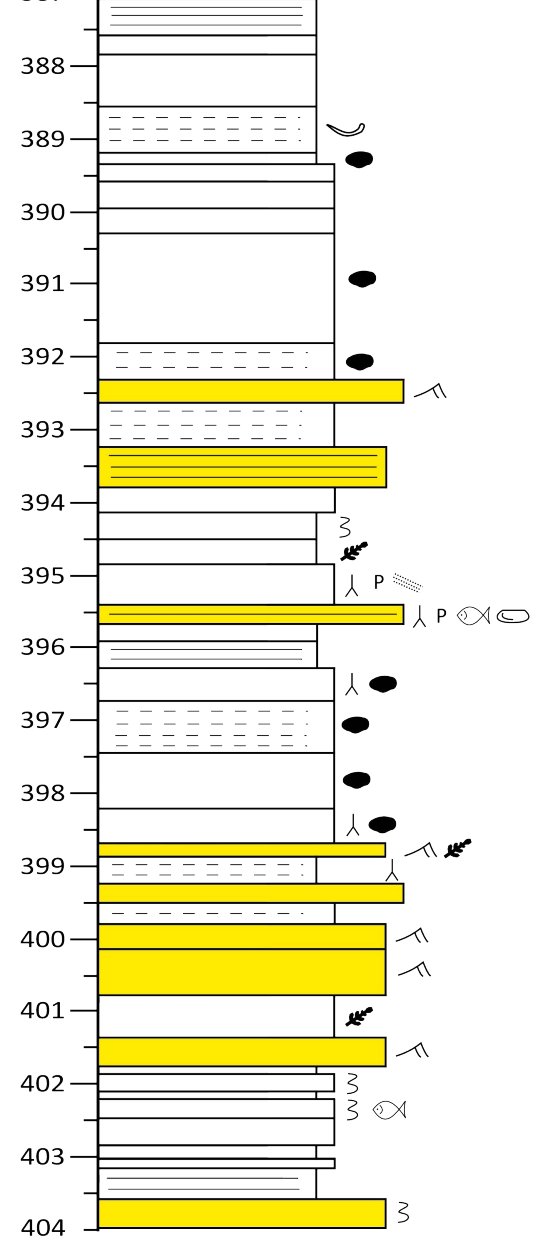

sandstone $\quad \lambda$ roots

dolostone lycopod roots

limestone * plant debris

evaporite

$G$ gypsum

plane lamination

weak lamination

$\sim$ cross-bedding

^ripple lamination

$\checkmark$ desiccation cracks

dolostone nodules

pseudomorphs

after halite
MUD SAND GRAVEL

Depth

Metre

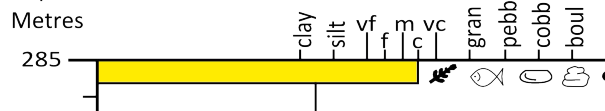

286

28

D $\&$

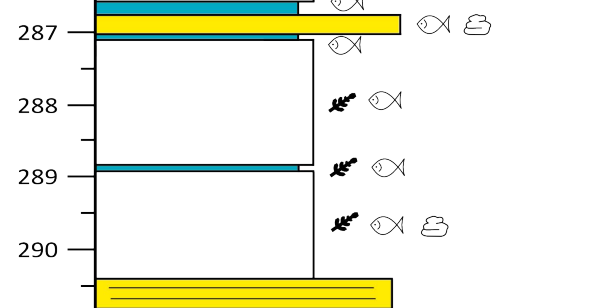

2

29

293

29

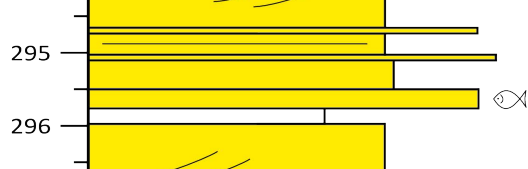

297

298

29

300

301

30

30

30

305

30

30

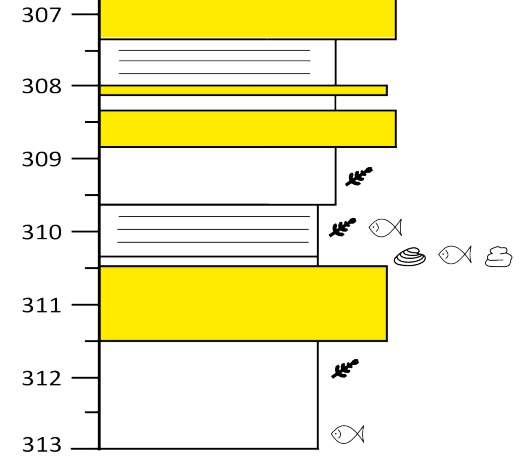




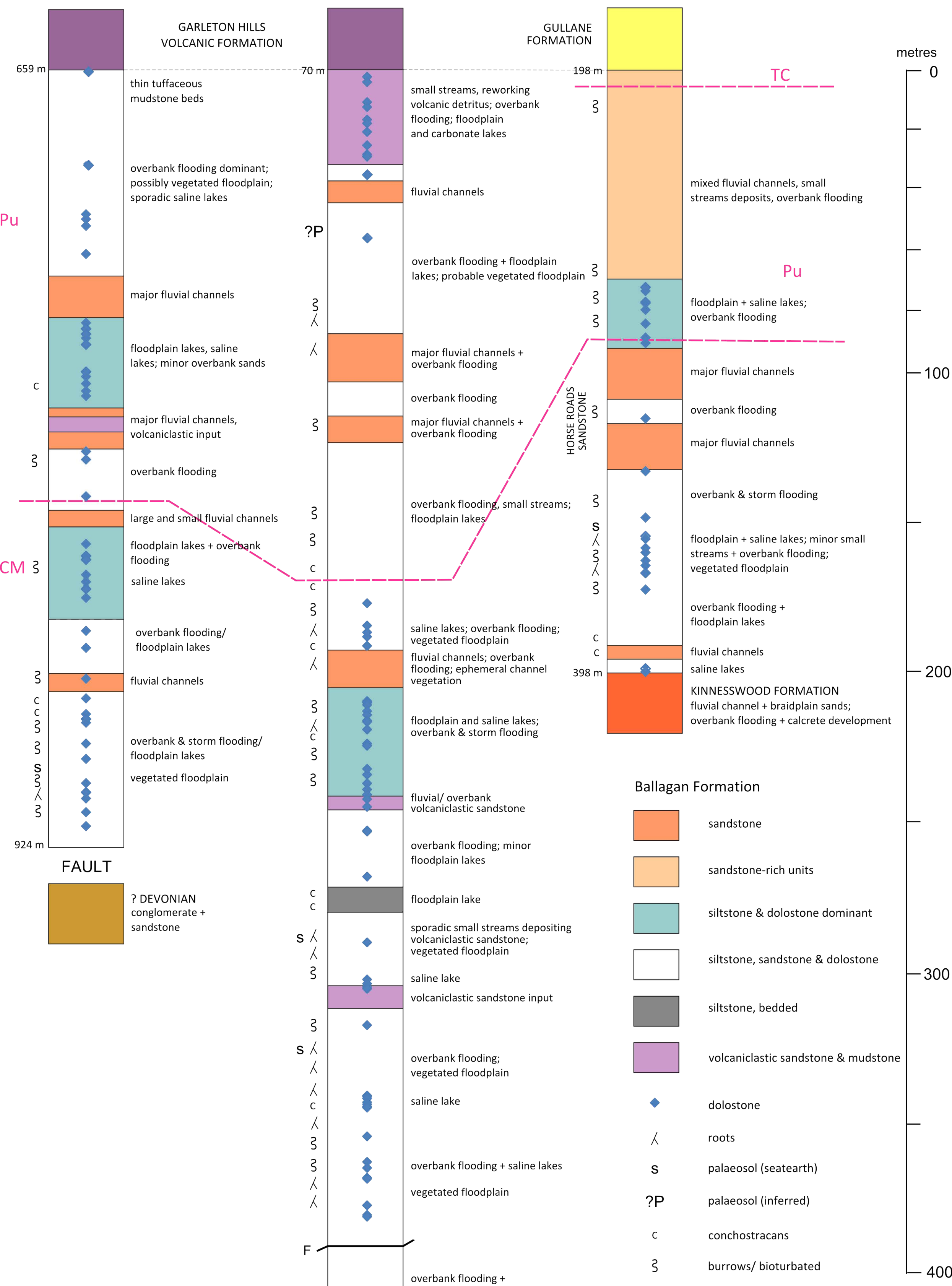




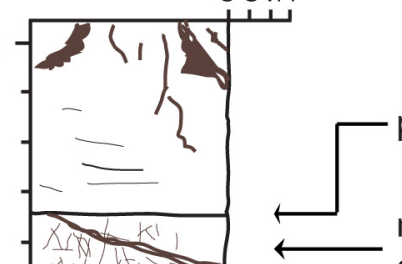

planar boundary

red clay, some dolomite
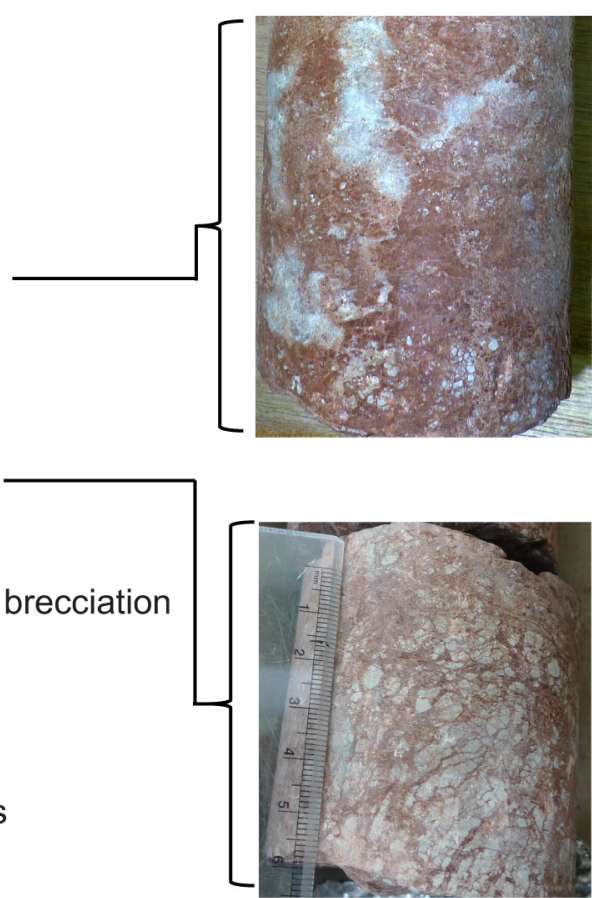

brecciation and greater

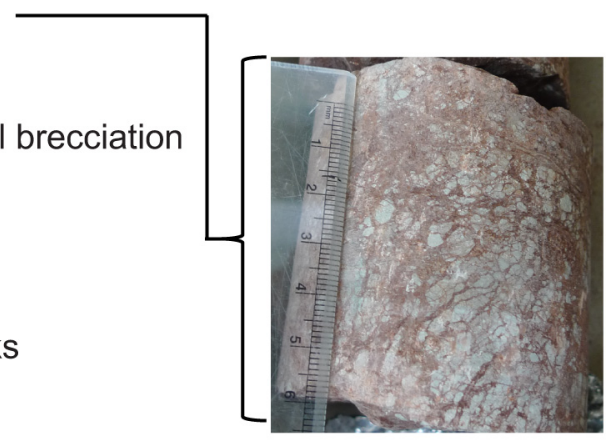

low angle, crescent like dislocations and internal brecciation cracks become joined and through going silty dolomicrite with isolated reddened cracks

sandy siltstone low angle, crescent like dislocations and internal brecciation

cracks become joined and through going

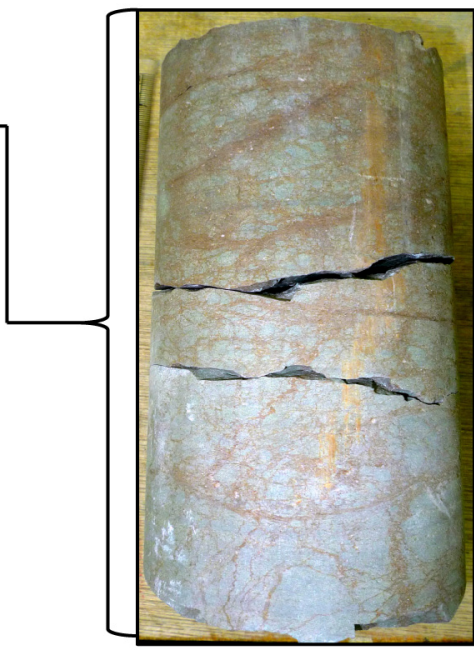

silty dolomicrite with

isolated reddened cracks 

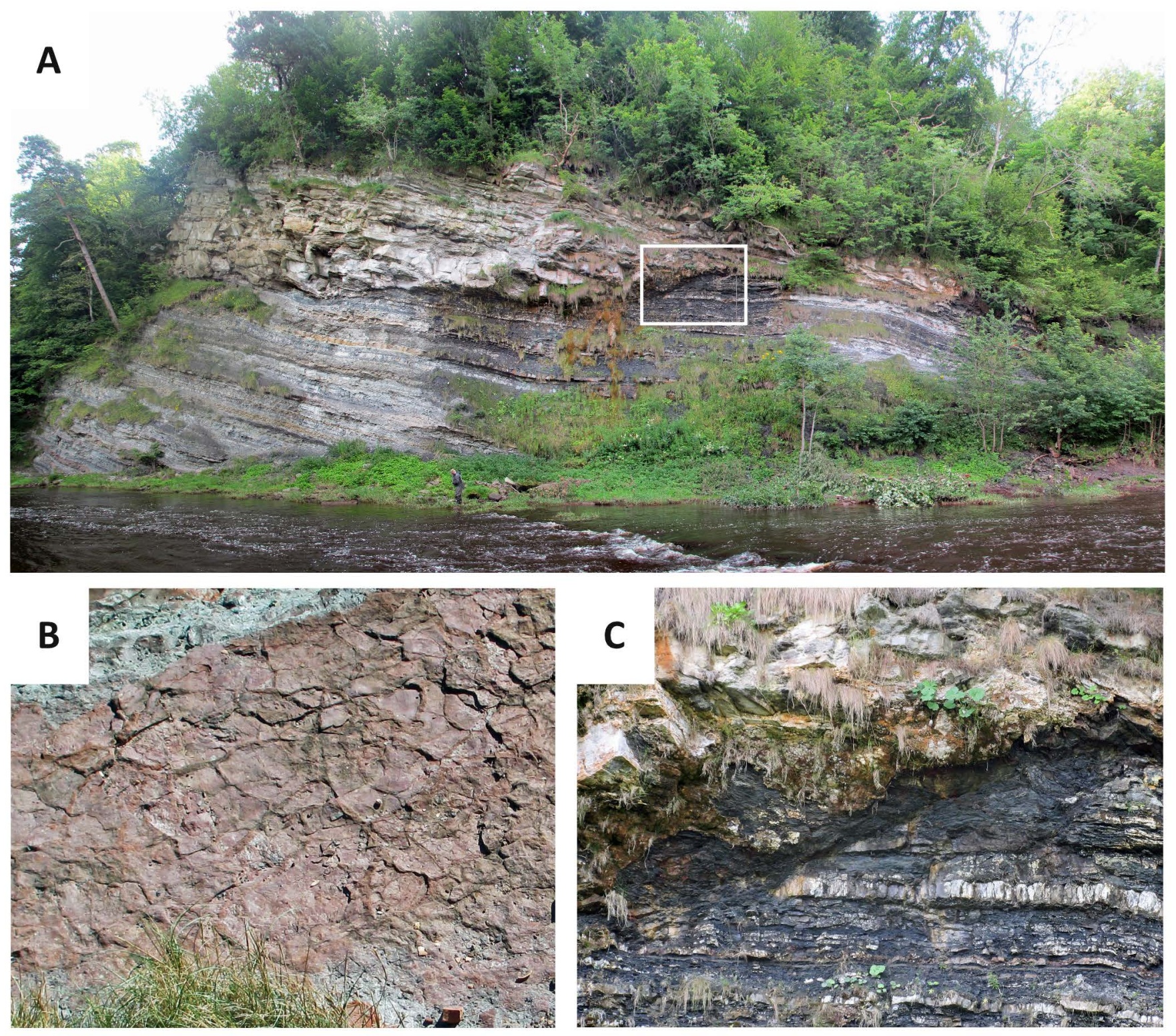

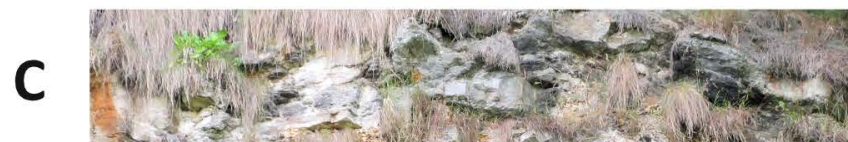

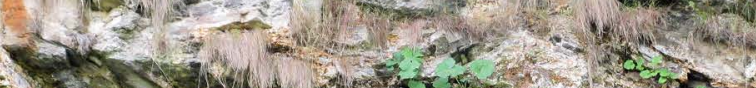

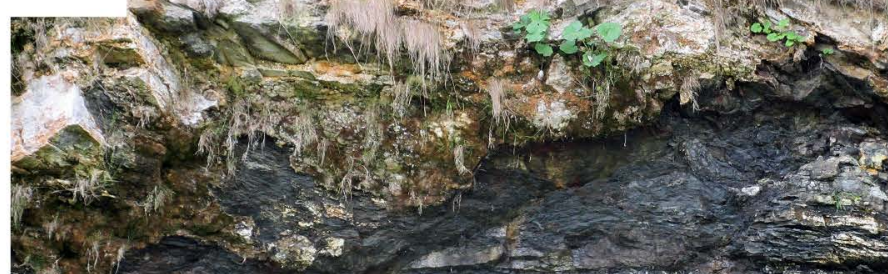

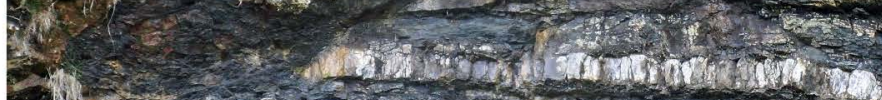

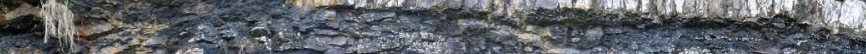

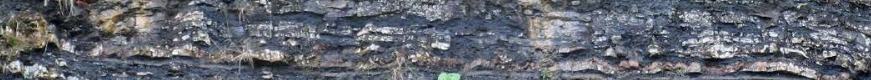

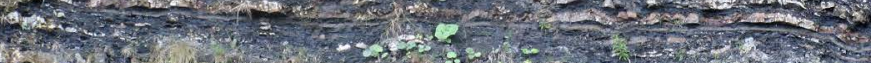

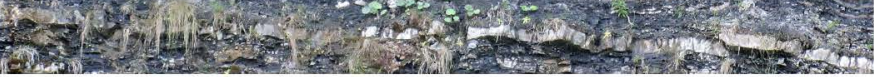
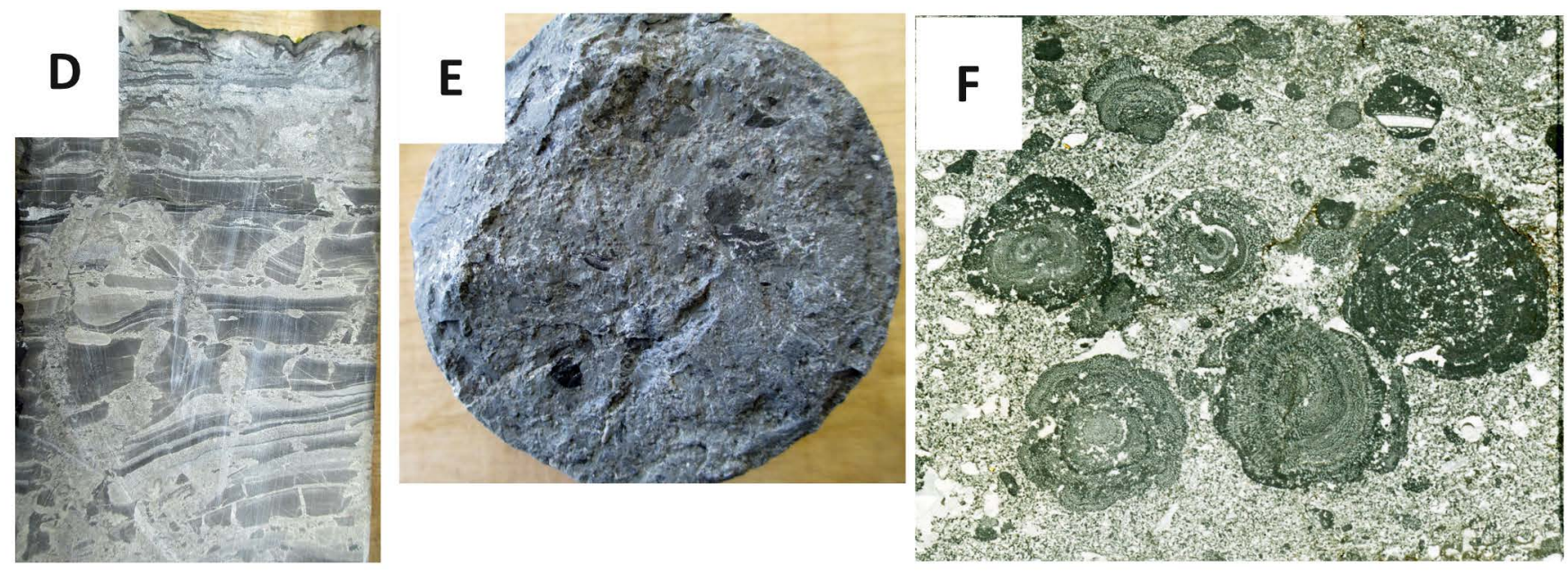


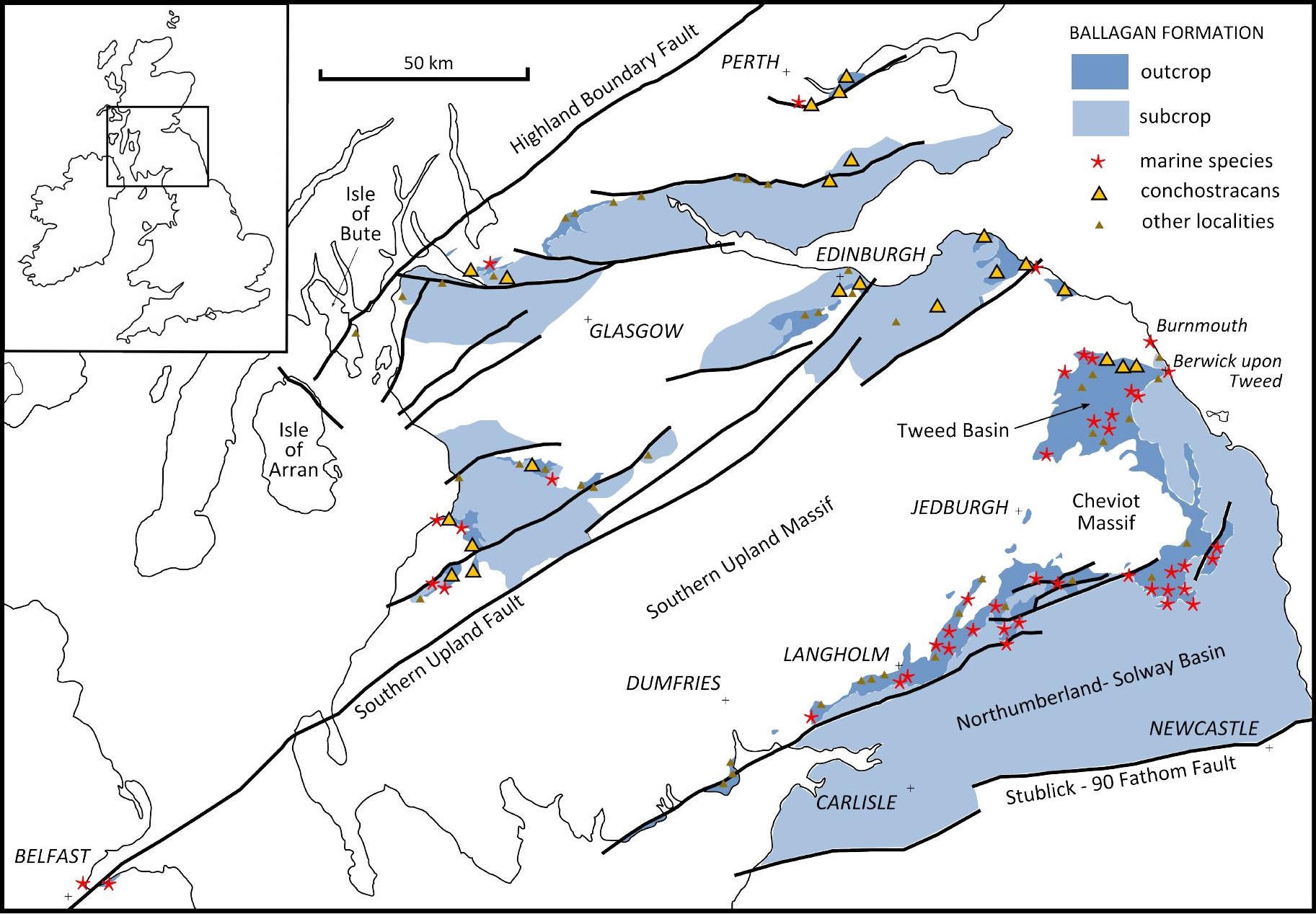




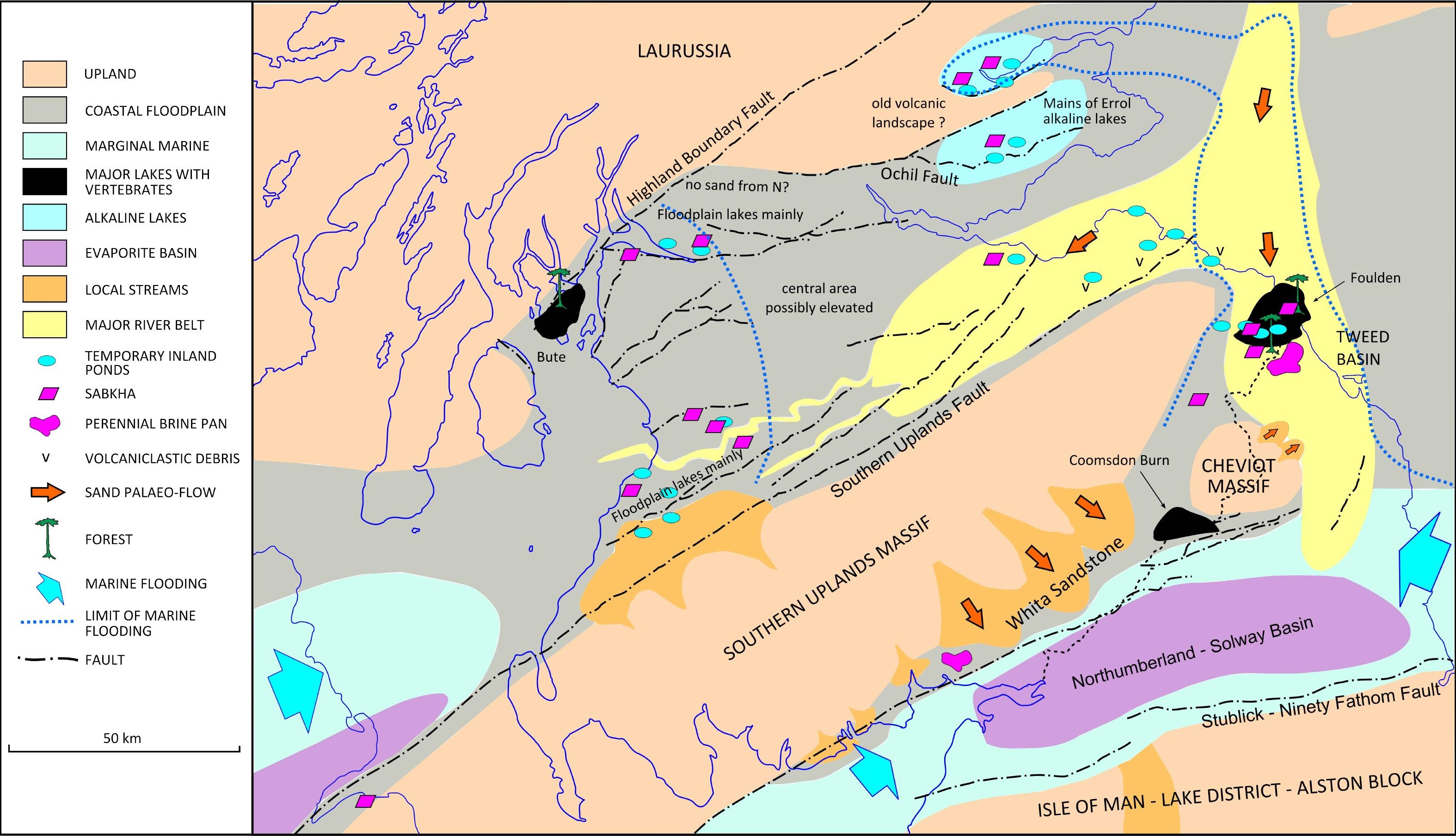


Table 1. Facies, facies associations and environments in the Ballagan Formation of the Midland Valley of Scotland and Tweed Basin. The marginal marine facies of the Lyne Formation Northumberland - Solway Basin are omitted. Facies descriptions are from the archived borehole logs in the BGS collections and from key exposures. Facies association after Bennett et al. (2016).

\begin{tabular}{|c|c|c|c|c|}
\hline Facies & Facies description & Where seen & Depositional environment & Facies association \\
\hline Dolostone & $\begin{array}{l}\text { Parallel beds of ferroan dolostone ('cementstone') and dolomitized siltstone; grey but some reddish } \\
\text { brown; hard, compact, splintery; sporadic records of ostracods, some with shell fragments and } \\
\text { Chondrites; some beds nodular or with bulbous base; varieties include laminated dolostone, others with } \\
\text { diffuse top and base; tops may be cracked or brecciated; commonly hosts evaporite nodules }\end{array}$ & $\begin{array}{l}\text { In all boreholes and } \\
\text { exposures, varying } \\
\text { abundance }\end{array}$ & $\begin{array}{l}\text { Saline - hypersaline flood- } \\
\text { plain lakes, cryptic marine } \\
\text { flooding }\end{array}$ & $\begin{array}{l}\text { Freshwater, saline } \\
\text { and hypersaline lake }\end{array}$ \\
\hline $\begin{array}{l}\text { Reddened } \\
\text { pseudobrecciated } \\
\text { dolostone }\end{array}$ & $\begin{array}{l}\text { Dolomicrite, bluish to greenish grey, pseudobrecciated, cracked and reddened profile; Fe-rich claystone } \\
\text { fills to cracks; low-angle, concave upwards fractures in upper part of profile resemble pedogenic } \\
\text { slickensides }\end{array}$ & $\begin{array}{l}\text { Mains of Errol Member, } \\
\text { Glenrothes, East Dron }\end{array}$ & $\begin{array}{l}\text { Desiccated hypersaline, } \\
\text { ?alkaline lakes }\end{array}$ & \\
\hline Limestone & $\begin{array}{l}\text { Grey limestone, porcellaneous, in part pseudobrecciated; or sandy, cross-bedded; with ostracods, fish } \\
\text { scales and teeth, Spirorbids }\end{array}$ & $\begin{array}{l}\text { Spilmersford, East Linton } \\
\text { (top part), Tantallan }\end{array}$ & Flood-plain lakes & \\
\hline Evaporite & $\begin{array}{l}\text { Diverse suite of subfacies of gypsum and anhydrite nodules, chicken-wire masses, evaporite-rock and } \\
\text { laminae, hosted by dolostone and laminated grey siltstone facies. Pseudomorphs after halite in siltstone } \\
\text { facies }\end{array}$ & $\begin{array}{l}\text { Widespread, except in East } \\
\text { Lothian }\end{array}$ & $\begin{array}{l}\text { Hypersaline lakes, brine } \\
\text { pans and sabka }\end{array}$ & \\
\hline $\begin{array}{l}\text { Laminated grey } \\
\text { siltstone }\end{array}$ & $\begin{array}{l}\text { Planar laminated grey and dark grey siltstone and mudstone; disseminated pyrite; ostracods, bivalves, } \\
\text { fish scales, conchostracans and burrows; sporadic marine taxa; desiccation cracks and roots generally } \\
\text { absent; typically interbedded with dolostone }\end{array}$ & $\begin{array}{l}\text { All boreholes and } \\
\text { exposures }\end{array}$ & $\begin{array}{l}\text { Flood-plain lakes, cryptic } \\
\text { marine flooding }\end{array}$ & \\
\hline $\begin{array}{l}\text { Heterogeneous } \\
\text { siltstone }\end{array}$ & $\begin{array}{l}\text { Grey, purple-grey, mottled grey and brown, red-brown or red and purple; massive to laminated, some } \\
\text { rippled or disturbed bedding; some rooting and Stigmaria. Interbedded with laminated or ripple- } \\
\text { laminated sandstone }\end{array}$ & $\begin{array}{l}\text { In all boreholes and } \\
\text { exposures }\end{array}$ & Overbank flooding & Overbank \\
\hline $\begin{array}{l}\text { Ripple-laminated } \\
\text { sandstone }\end{array}$ & $\begin{array}{l}\text { Ripple-laminated or cross-laminated, fine-grained with siltstone laminae; plant, shell and fish debris; } \\
\text { bioturbation in some beds, sporadic records of ?Monocraterion and Planolites; interbedded with } \\
\text { siltstone; units typically }<3 \mathrm{~m}\end{array}$ & $\begin{array}{l}\text { In all boreholes and } \\
\text { exposures }\end{array}$ & $\begin{array}{l}\text { Overbank and storm } \\
\text { flooding into lakes; small } \\
\text { stream deposits }\end{array}$ & \\
\hline Palaeosols & $\begin{array}{l}\text { Few identified in logs; best indicator is record of carbonized root traces in grey siltstone and 'seatclay' or } \\
\text { 'seatearth' (?gleyed inceptisols) but depth of rooting and thickness not given; also rooted fine-sandstone } \\
\text { (?entisols); unbedded mottled red-brown siltstone may represent vertisols }\end{array}$ & $\begin{array}{l}\text { Most boreholes; Bute, } \\
\text { Burnmouth }\end{array}$ & Vegetated flood-plain & \\
\hline $\begin{array}{l}\text { 'Mudstone breccia' } \\
\text { (sandy siltstone?) }\end{array}$ & $\begin{array}{l}\text { Greenish grey dolomitized siltstone with irregular dark grey siltstone clasts up to } 10 \mathrm{~mm} \text {. Beds } 10-84 \mathrm{~cm} \text {. } \\
\text { (described similarly as 'Clast-rock' in Ascog) }\end{array}$ & $\begin{array}{l}\text { Glenrothes, East Dron, } \\
\text { Ascog }\end{array}$ & $\begin{array}{l}\text { Unconfined debris-flow } \\
\text { deposit }\end{array}$ & \\
\hline Conglomerate & $\begin{array}{l}\text { Round dolostone clasts } 1-20 \mathrm{~mm} \text { diameter with calcareous mudstone matrix; plant fragments; beds } 18 \\
\mathrm{~cm} \text {, siltstone above and below }\end{array}$ & East Linton, Everton & $\begin{array}{l}\text { Unconfined debris-flow } \\
\text { deposit }\end{array}$ & \\
\hline $\begin{array}{l}\text { Cross-bedded } \\
\text { sandstone }\end{array}$ & $\begin{array}{l}\text { Fine, medium and coarse-grained sandstone, trace siltstone; conglomerate at base in some units; } \\
\text { carbonaceous and micaceous coatings to laminae; massive or cross-bedded, some convolute bedded; } \\
\text { some units ripple laminated towards top; sporadic beds with mudstone flakes. Units } 3-15 \mathrm{~m} \text { thick. Unit } \\
\text { base sharp, irregular, erosive. Minor bioturbation, rooting at top. Plant debris, 'Stigmaria' pieces. }\end{array}$ & $\begin{array}{l}\text { Spilmersford, East Linton, } \\
\text { Birnieknowes, Marshall } \\
\text { Meadows, Blairmulloch; } \\
\text { Edington Mill }\end{array}$ & Fluvial channels & Fluvial \\
\hline $\begin{array}{l}\text { Volcaniclastic } \\
\text { sandstone }\end{array}$ & $\begin{array}{l}\text { 'Tuff', 'agglomerate', and tuffaceous siltstone and sandstone; grain size from medium to coarse sand, } \\
\text { granules and pebbles, coarsest up to } 15 \mathrm{~cm} \text {; clasts of green amygdaloidal 'lava'; dolostone, siltstone; } \\
\text { bedded units up to } 2.5 \mathrm{~m} \text { thick, occurring sporadically and in packages up to } 8 \mathrm{~m} \text {. }\end{array}$ & East Linton, Spilmersford & $\begin{array}{l}\text { Reworked older volcanic } \\
\text { deposits and ripped-up } \\
\text { substrate, probably fluvial }\end{array}$ & \\
\hline
\end{tabular}


1 Table 2. Summary statistics for Ballagan Formation in selected BGS boreholes

\begin{tabular}{|c|c|c|c|c|c|c|c|c|c|c|c|c|c|c|}
\hline \multirow{2}{*}{$\begin{array}{l}\text { Borehole } \\
\text { name }\end{array}$} & \multirow{2}{*}{$\begin{array}{c}\text { BGS } \\
\text { Registered } \\
\text { number }\end{array}$} & \multirow{2}{*}{$\begin{array}{c}\text { BGN } \\
\text { thickness } \\
\text { metres }\end{array}$} & \multirow{2}{*}{$\begin{array}{c}\text { Unit } \\
\text { above }\end{array}$} & \multirow{2}{*}{$\begin{array}{c}\text { Unit } \\
\text { below }\end{array}$} & \multirow{2}{*}{$\begin{array}{c}\text { Sandstone } \\
\% \text { of } \\
\text { formation }\end{array}$} & \multicolumn{4}{|c|}{ Dolostones (cementstones) } & \multirow{2}{*}{$\begin{array}{l}\text { Number } \\
\text { desiccation } \\
\text { crack } \\
\text { horizons }\end{array}$} & \multirow{2}{*}{$\begin{array}{c}\text { Number } \\
\text { beds } \\
\text { burrowed/ } \\
\text { bioturbated }\end{array}$} & \multirow{2}{*}{$\begin{array}{c}\text { Number } \\
\text { rooted } \\
\text { horizons/ } \\
\text { palaeosols }\end{array}$} & \multirow{2}{*}{$\begin{array}{c}\text { Number } \\
\text { evaporite } \\
\text { units }\end{array}$} & \multirow{2}{*}{$\begin{array}{c}\% \text { fines } \\
\text { grey and } \\
\text { bedded }\end{array}$} \\
\hline & & & & & & $\begin{array}{l}\text { No of } \\
\text { beds }\end{array}$ & $\begin{array}{l}\text { As \% of } \\
\text { fines }\end{array}$ & $\begin{array}{c}\text { bed } \\
\text { thickness } \\
\text { centimetres }\end{array}$ & $\begin{array}{c}\text { frequency, } \\
\text { metres, } \\
\text { sand free }\end{array}$ & & & & & \\
\hline Ascog & NS06SE 8 & 33.09 & CYD & KNW & 27.8 & 9 & 3.4 & 9.1 & 2.65 & 0 & 0 & 0 & 0 & n.d.* \\
\hline Knocknairshill & NS37SW10 & 70.87 & CYD & KNW & 20.6 & 33 & 7.5 & 12.9 & 1.70 & 8 & 0 & 0 & 17 & 49 \\
\hline Barnhill & NS47NW 2 & 123.08 & CYD & KNW & 8.0 & 82 & 11.4 & 15.7 & 1.38 & 2 & 6 & 0 & 30 & 85 \\
\hline $\begin{array}{l}\text { Loch } \\
\text { Humhrey }\end{array}$ & NS47NE 1 & 162.95 & CYD & $\begin{array}{l}\text { Not } \\
\text { reached }\end{array}$ & 6.7 & 126 & 12.4 & 15.1 & 1.21 & 6 & 2 & 0 & 64 & 89 \\
\hline East Dron & NO11NW 24 & 209.54 & Not seen & KNW & 9.7 & 127 & 10.9 & 16.3 & 1.49 & 110 & 45 & 10 & 114 & 57 \\
\hline Glenrothes & NO20SE 385 & 157.43 & PDB & KNW & 7.5 & 159 & 18.0 & 16.5 & 0.92 & 137 & 21 & 2 & 47 & 83 \\
\hline Deaconhill & NS43SE 81 & 150.03 & LLGS & KNW & 1.9 & 94 & 16.0 & 25.1 & 1.57 & 4 & 9 & 2 & 12 & 94 \\
\hline Blairmulloch & NS52NE 21 & 166.58 & CYD & $\begin{array}{l}\text { Not } \\
\text { reached }\end{array}$ & 14.8 & 83 & 11.5 & 19.65 & 1.71 & 3 & 21 & 1 & 34 & 99 \\
\hline Spilmersford & NT46NE 73 & 258.24 & GHV & Fault & 31.9 & 63 & 8.3 & 23.1 & 2.82 & 7 & 24 & 2 & 0 & 44 \\
\hline East Linton & NT57NE 2 & 418.17 & GHV & $\begin{array}{l}\text { Not } \\
\text { reached }\end{array}$ & 23.8 & 59 & 6.6 & 34.1 & 5.41 & 15 & 62 & 26 & 0 & 42 \\
\hline Birnieknowes & NT77SE 9 & 200.21 & GUL & KNW & 46.5 & 33 & 5.0 & 16.3 & 3.24 & 2 & 20 & 1 & 0 & 59 \\
\hline Norham & NT94NW 20 & 490.50 & Not seen & $\begin{array}{l}\text { Not } \\
\text { reached }\end{array}$ & 35.5 & 277 & 21.5 & 24.5 & 1.14 & 131 & 128 & 216 & 50 & 16 \\
\hline
\end{tabular}

2 Unit codes: BGN Ballagan Formation; CYD Clyde Sandstone Formation; FESD Fell Sandstone Formation, GHV Garleton Hills Volcanic Formation, GUL Gullane Formation, KNW Kinnesswood

3 Formation, LLGS Lower Limestone Formation

$4 \quad$ *Log descriptions of mudstone and siltstone units in the Ascog Borehole contain insufficient detail for analysis 